\title{
A research agenda for the restoration of tropical and subtropical grasslands and savannas
}

Running title (3 to 6 words): Research agenda for tropical grassland restoration

Elise Buisson ${ }^{1,2 *}$, Alessandra Fidelis ${ }^{3}$, Gerhard E. Overbeck ${ }^{4}$, Isabel B. Schmidt ${ }^{5}$, Giselda Durigan $^{6}$, Truman P. Young ${ }^{2}$, Swanni T. Alvarado ${ }^{7}$, André J. Arruda ${ }^{1,8}$, Sylvain Boisson ${ }^{9}$, William Bond ${ }^{10}$, André Coutinho ${ }^{11}$, Kevin Kirkman ${ }^{12}$, Rafael S. Oliveira ${ }^{13}$, Melissa H. Schmitt ${ }^{14,15}$, Frances Siebert ${ }^{16}$, Stefan J. Siebert ${ }^{16}$, Dave I. Thompson ${ }^{14,17}$, Fernando A. O. Silveira ${ }^{8}$

1. Avignon Université, Institut Méditerranéen de Biodiversité et d'Ecologie - IMBE, CNRS, IRD, Aix Marseille Université, IUT d'Avignon, AGROPARC BP61207, 84911 Avignon cedex 9, France

2. Department of Plant Sciences, University of California, Davis, CA 95616, USA

3. Lab of Vegetation Ecology, Instituto de Biociências, Universidade Estadual Paulista (UNESP), Av. 24A, 1515, 13506-900, Rio Claro, SP, Brazil

4. Departamento de Botânica, Universidade Federal do Rio Grande do Sul, Av. Bento Gonçalves 9500, CEP 91501-970, Porto Alegre, RS, Brazil

5. Department of Ecology, University of Brasília, Campus Universitário Darcy Ribeiro, Brasilia, Brazil

6. Floresta Estadual de Assis, Instituto Florestal do Estado de São Paulo, P.O. Box 104, 19802970, Assis, SP, Brazil

This article has been accepted for publication and undergone full peer review but has not been through the copyediting, typesetting, pagination and proofreading process which may lead to differences between this version and the Version of Record. Please cite this article as doi: $10.1111 /$ rec.13292 
7. Programa de Pós-graduação em Agricultura e Ambiente \& Programa de Pós-graduação em Geografia, Natureza e Dinâmica do Espaço, Universidade Estadual do Maranhão, São Luís, Maranhão, Brazil.

8. Departamento de Genética, Ecologia e Evolução, Instituto de Ciências Biológicas, Universidade Federal de Minas Gerais, Av. Antônio Carlos 6627, CEP 31270-901, Belo Horizonte, MG, Brazil

9. Université de Liège Gembloux Agro-Bio Tech, Biodiversity and Landscape, TERRA, Gembloux, Belgium

10. Department of Biological Sciences, University of Cape Town, Rondebosch, South Africa

11. Universidade de Brasília, Biologia, SMDB Conjunto 23 Lote 2C, Brasília DF, Brazil

12. University of KwaZulu-Natal, School of Life Science, Pietermaritzburg, KwaZulu-Natal, South Africa

13. Department of Plant Biology, Institute of Biology, University of Campinas - UNICAMP, Campinas, SP, Brazil

14. South African Environmental Observation Network, Ndlovu Node, Scientific Services, Kruger National Park, Private Bag X1021, Phalaborwa 1390, South Africa

15. University of California Santa Barbara, Department of Ecology, Evolution, and Marine Biology, Santa Barbara, CA, USA

16. North-West University, Unit for Environmental Sciences and Management, 11 Hoffman Street, Potchefstroom, 2531 Potchefstroom, North-West, South Africa

17. School of Geography, Archaeology, and Environmental Studies, University of the Witwatersrand, Private Bag 3 WITS 2050, South Africa

Author contributions: EB, FAOS, RSO conceived and organized the original symposium at the 2019 SER World Conference; EB, AF, GEO, IBS, GD, TPY, STA, FAOS prepared the first 
draft; all authors actively discussed ideas, contributed with writing topics, revised, and approved the final version of the manuscript.

\section{Abstract}

Despite growing recognition of the conservation value of grassy biomes, our understanding of how to restore biodiverse tropical and subtropical grassy biomes (grasslands and savannas; TGB) remains limited. Several tools have recently been identified for TGB restoration including prescribed fires, appropriate management of livestock and wild herbivores, tree cutting and shrub removal, invasive species control and the reintroduction of native grasses and forbs via seeding or transplants. However, additional research for improved TGB restoration is needed. This paper aims to identify ecological research priorities for TGB restoration. The following points are crucial to scale up TGB restoration and meet the challenges of the UN Restoration Decade. Research should focus on: disentangling the reasons why TGB are often undervalued and misunderstood; mapping TGB restoration opportunities; identifying regions where TGB and other biomes naturally exist as alternative stable states; recognizing areas with natural regeneration potential to avoid unnecessary intervention; restoring soil conditions; disentangling factors driving low seed quality, determining germination requirements and developing vegetative propagation techniques for TGB species; disentangling the limiting factors and key ecological processes underlying seedling establishment and community assembly; improving and validating long-term management to mimic natural disturbance regimes; setting the minimum 
attributes of desirable TGB in terms of structure, composition, functioning and resilience; and improving monitoring of restoration outcomes. Such research has the potential to advance theory, policy and practice in TGB restoration, ultimately resulting in long-term benefits for people and nature in some of the more neglected ecosystems of our planet.

Keywords: grassy biomes; old-growth grasslands; tropical old-growth grassy biomes; grasslands; savannas; woodlands

\section{Conceptual implications}

- TGB restoration cannot be upscaled if these ecosystems remain poorly known and undervalued, if their ecosystem services are not perceived or realized, and if the representation of restoration opportunities remains misleading.

- Low seed quality, germination and plant establishment must be investigated and overcome using innovative technologies to enhance restoration practice.

- Plant propagation techniques must be developed to facilitate the reintroduction of the large proportion of TGB species whose populations do not readily regenerate from the seed bank or seed rain.

- Critical research also includes finding the best practices for site preparation to preserve/recover soil properties in sustainable TGB restoration. 
- Monitoring should be evidence-based to assess whether desirable structure, composition, functioning and especially resilience of a TGB have been recovered. 


\section{Introduction}

International incentives in the last decade have brought ecological restoration to the forefront of proposed solutions to mitigate the impact of ecosystem degradation worldwide (Temperton et al. 2019). Ten years ago, the UN Convention on Biological Diversity proposed that $15 \%$ of degraded ecosystems be restored by 2020 (CBD 2011), whereas the Bonn Challenge aimed specifically at "restoring” (i.e., reforesting) 150 million hectares of the world's deforested and degraded land by 2020, and 350 million hectares by 2030 (IUCN-DC 2011). These initiatives were subsequently endorsed by the New York Declaration on Forests at the 2014 UN Climate Summit (Climate Summit 2014) and by the UN Sustainable Development Goals (IRP 2019). Recently, the UN Environment Program declared 2021 - 2030 to be the "UN Decade on Ecosystem Restoration” (UN-Environment Programme 2019). Unfortunately, such policies are strongly forest- and tree-oriented, overestimate the potential of tree planting as a means of climate mitigation (Veldman et al. 2019), and do not fully acknowledge limits linked to forest stability and important ecological and climate-related risks (Anderegg et al. 2020). The intense pressure to afforest has even been identified as a major threat to non-forest ecosystems and human livelihoods (Johansson et al. 2020, Tölgyesi et al. 2020; Fagan 2020), and provides a compelling reason for establishing a detailed research agenda for the restoration of overlooked and misinterpreted open ecosystems (Temperton et al. 2019), including tropical grassy biomes.

Upscaling restoration, however, is challenging as it requires knowledge of natural ecosystems and their socio-economic context, and solid links between science and practice 
(Miller et al. 2017; Cooke et al. 2019; Gann et al. 2019). Major hurdles limiting appropriate restoration and management of old-growth tropical and subtropical grasslands and savannas (TGB i.e. Tropical Grassy Biomes) have been recently identified (Buisson et al. 2019), yet it is unclear how to achieve the deeper scientific knowledge necessary to overcome such hurdles. TGB are megadiverse, ancient ecosystems with a continuous herbaceous cover composed of graminoids and forbs, with or without scattered shrubs and trees (Veldman et al. 2015). TGB are largely threatened by agricultural conversion, opencast mining, anthropogenic increases in or suppression of fires, mismanaged livestock, wood extraction, invasive species, and afforestation (Veldman et al. 2015). Such threats compromise biodiversity, ecosystem functioning, and human livelihoods. Owing to large knowledge gaps and widespread misconceptions concerning their basic ecology (Silveira et al. online early; Bond 2019), large-scale restoration in these key ecosystems is not yet feasible, despite their rich biodiversity, provision of ecosystem services and direct support of human livelihoods. Clearly, international agreements should recognize and endorse the fact that forests are not the only ecosystems in need of restoration, to make funding and government incentives available for the restoration of open ecosystems. Additionally, limited knowledge of the ecology and restoration of TGB reinforces the need for prioritization of research efforts to support and foster practices aimed at accelerating TGB restoration.

Here we propose a research agenda to guide research priorities for TGB restoration. We identify emerging issues across broad themes in restoration to structure questions aimed at optimizing practical restoration outcomes (Miller et al. 2017; Figure 1). Our focus is on the 
ecological dimensions of restoration ecology, but we also recognize the need for similar efforts towards socio-ecological dimensions of restoration (sensu Perring et al. 2015). Most of the questions we identify are from the perspective of the vegetation, but we also address some priority issues concerning herbivores in tropical grassy biomes.

\section{Changing perceptions on Tropical Grassy Biomes (TGB)}

Misunderstandings and misconceptions concerning the ecology of open ecosystems (Bond 2019, Fagan 2020) have led to pristine TGB being confused with degraded or secondary grasslands (e.g. TGB transformed to pastures) or with derived grasslands and savannas (e.g. grasslands derived from the degradation of forests), with subsequent recommendations for restoration directed at tree planting (Silveira et al. online early; Schmidt et al. 2019a; Figure 2). TGB are often thought to be by-products of forest degradation, despite clear criteria for identifying TGB being available (Veldman et al. 2015). Such misidentification of TGB results in ill-conceived restoration policies, including afforestation (Veldman 2016; Bond 2019). TGB have been demonstrated to be slow to recover if degraded by exogenous disturbances (Nerlekar \& Veldman 2020).

Disentangling the reasons why TGB are often undervalued and misunderstood (Parr et al. 2014; Veldman et al. 2017) is a major research question which cannot be tackled by restoration ecologists alone, but calls for integration with environmental sociology. This research is likely to 
provide conditions to change the historical prejudice against open ecosystems (Bond 2019) that will promote best restoration practices and policy. Such a changed perspective can also be supported by better communication of the high benefit-cost ratios of TGB restoration (De Groot et al. 2013) and by the plethora of ecosystem services provided by restored ecosystems (Morecroft et al. 2019). Restoration benefits and costs should be identified regionally to provide support for practical decisions in TGB restoration. Socio-ecological research is needed to demonstrate the value and importance of the ecosystem services provided by TGB (Bengtsson et al. 2019), which can include, but should not be limited to carbon sequestration, which is the standard approach used in forested landscape restoration initiatives.

\section{Defining TGB restoration opportunities and targets}

\section{Restoration opportunities}

Identifying restoration opportunities for TGB requires: 1) information on the distribution of TGB, as well as degraded and derived grasslands at different scales, 2) finer-scale information on the distribution of TGB and 3) potential socio-economic constraints to feasibility, all of which can be mapped. Setting restoration priorities entails valuation of restoration benefits to society and using scientific evidence to make appropriate, informed and transparent prioritization decisions. 
1) A critical step to adequately plan restoration is to have reliable information on the distribution of different grassland types, information that is not readily available in many tropical and subtropical regions. Ideally, mapping the global and regional distribution of grasslands should be aligned with mapping the distribution of forests, thus avoiding the kinds of overlap pointed out by Veldman et al. (2015). Careful planning for TGB restoration includes proper identification of: i) pristine TGB as reference ecosystems; ii) degraded TGB which constitute restoration targets; and iii) degraded forests converted to derived grasslands and savannas which constitute reforestation targets. Mapping these three ecosystem-types using remote sensing data derived from satellites should provide important information for regional and global analyses. However, because of their temporal and spatial resolution limitations, remote sensing techniques may not be precise enough and fail to distinguish TGB from degraded and derived grasslands (Veldman \& Putz 2011). The recent GEDI - Global Ecosystem Dynamics Investigation - provides a powerful option to identify the complexity of TGB. First, it uses a high-resolution laser that allows quantification of the vertical distribution of vegetation and estimates variables including surface topography, canopy height and cover metrics, and vertical structure metrics (Dubayah et al. 2020). Second, GEDI-derived data can be downloaded for free. The feasibility of using both vertical and horizontal information to facilitate floristic differentiation and allow the separation of TGB from degraded and derived grasslands needs to be empirically tested. Remote sensing assessments should be coupled with in situ biodiversity assessments to calibrate the models and produce a reliable global map of TGB restoration opportunities. Large-scale mapping should also 
incorporate spatial autocorrelation and spatial structure data to improve the predictive ability of mapping opportunities for restoration at the global scale (Ploton et al. 2020).

2) In many regions, TGB are composed of multiple grass-dominated ecosystems found in mosaics including woody vegetation types (Sankaran et al. 2005): i) forming a continuum from grassland and savanna to closed-canopy woodland and forests; ii) representing mosaics of natural alternative stable states in the landscape (Bond 2019); and iii) characterizing patterns due to edaphic factors or disturbance (Buisson et al. 2019; Le Stradic et al. 2015a; Figure 3). Each grassland type should be restored where it belongs, recreating mosaics to restore biodiversity and services at the landscape-scale, and maintained using management or natural disturbances.

3) Restoration opportunities are often constrained by environmental legislation, social will and available resources to implement restoration. Therefore, socio-ecological benefits should also be mapped and integrated in the definition of restoration opportunities (Brancalion et al. 2019). Funds for landscape-scale restoration have increased more rapidly for forest than for non-forest ecosystems (Veldman et al. 2015; Overbeck et al. 2015). Since fund availability changes quickly in space and time in unpredictable ways, frequent updating of this information is required.

\section{Setting restoration targets}


Identifying pristine ecosystems as references is challenging for TGB restoration because i) they are old-growth ecosystems and their restoration is often unachievable on human timescales (Veldman et al. 2015); ii) pristine ecosystems of a particular region may no longer exist; and iii) the highly dynamic nature of ecosystems (Higgs et al. 2018), particularly in response to periodic disturbance, hinder simple restoration targets. Nonetheless, identifying a reference ecosystem (or preferably a regional range) is critical in restoration planning. In many situations, finding a reference ecosystem is challenging where alternative stable states naturally exist, opening the possibility of restoring any of a range of savanna-forest transition states in the landscape (Bond 2019). Setting restoration goals for a particular project also requires discernment between what is desirable and what is possible under the local constraints and the needs of local communities (Ehrenfeld 2000). Ideally, restored ecosystems should be structurally similar to the reference ecosystem, be composed by a subset of species from the regional pool, and have sufficient functional diversity to sustain ecosystem functioning. It is crucial for these restored TGB ecosystems to be resilient to endogenous disturbances (i.e. disturbances that are part of the evolutionary history and internal dynamics of a system). Optimizing goal-setting for TGB restoration relies on multidisciplinary research aimed at: i) identifying the pre-existing vegetation type under the same climatic conditions; ii) recognizing potential alternative stable states and disrupting internal feedbacks to allow the transitions from degraded to the desirable states (Suding et al. 2004); iii) diagnosing the potential for natural regeneration before deciding to intervene (Zahawi et al. 2015; Meli et al. 2017) given the unclear relative (cost-)effectiveness of 
passive versus active restoration in TGB; and iv) defining fundamental attributes for the TGB to be restored.

\section{Developing techniques to restore soil conditions}

When degradation entails total or partial loss of desirable soil characteristics, earthwork may constitute the first restoration step, as in cases of post-mining restoration. While re-profiling mine sites is often done (Figure 4), restoring hydrological processes (including restoring soil infiltration capacity or reducing surface runoff), soil structure (the degree of aggregate stability), chemical properties and microbial ecology (decomposition and nutrient cycling) are poorly studied for TGB.

Soil aggregation is the result of soil biota and their organic products, and a driver of soil water movement and retention, erosion, crusting, nutrient recycling, root penetration and productivity (Bronick \& Lal 2005). Soil aggregate stability is often degraded by management or restoration interventions, such as soil tillage (Plante \& McGill 2002), so understanding how to restore soil aggregation in TGB, aiming at preserving both soil biota and hydrological processes, is key to improve restoration success.

For less extreme degradations, soil preparation may be the first step in restoration. Tilling may efficiently break sealed soil surfaces (Kinyua et al. 2010; Figure 5) and topsoil removal may 
reduce the seed bank of undesirable species (Pilon et al. 2018; Sampaio et al. 2019). Creating microtopography can contribute to reduced soil erosion and increase the capture of soil and seeds from the surrounding landscape (Kimiti et al. 2017). Overall, however, benefits and potential negative consequences of soil preparation have seldom been studied in TGB. Little is known about the effect of these practices on biological soil crusts. Techniques should be tested more widely, diversified (e.g. soil inversion), and compared. Many TGB species have a bud bank or underground storage organs that confer resilience to aboveground endogenous disturbances such as fire and herbivory (Figure 6). Therefore, disrupting the soil is advised only if the degradation has already largely eliminated the underground component of the vegetation (Buisson et al. 2019). If the soil has not been disturbed or compacted, soil preparation is likely to be inappropriate, as it will hamper recovery from the seed and bud bank. Fertilization degrades many TGB on nutrient-poor soils (Harpole et al. 2016) and techniques to reduce soil nutrients, such as mowing and exporting biomass, carbon amendment, and grazing (Sitters et al. 2020) warrant further exploration. In sum, restoring the physical and chemical properties of soils may be the key first step to restore an important ecological filter that impacts community assembly and desired restoration goals such as resilience and ecosystem functioning (Figure 5).

\section{Reintroducing native species from seed}


Extensive knowledge gaps in basic seed biology of TGB species severely limit our capacity to use seed-based restoration strategies. Landscape-scale restoration requires large quantities of seeds, but many TGB herbaceous species have traits that limit seed sourcing, including: i) small populations, individual rarity, and irregular fruiting phenology (Dayrell et al. 2016); ii) low resource allocation to reproduction (Bond \& Midgley 2001); iii) recalcitrant seeds in forbs that impede seed storage; iv) high seed dormancy that inhibits germination (Rusdy 2017); v) low seed quality (low viability, high percentage of empty seeds, Dairel \& Fidelis online early; Kolb et al. 2016; Dayrell et al. 2017); and vi) fire-dependent flowering, seed release, or germination (Bond 2019). Seed germination of herbaceous species is often low, slow, and asynchronous. Therefore determining germination requirements (including fire-related cues), dormancy classes for TGB species, and methods to overcome dormancy, will be useful to optimize seedling establishment and decrease costs, increase the number of herbaceous species included in restoration programs (Ladouceur et al. 2018), and avoid scenarios where shorter-lived species are preferred over longlived perennials because of a shortage of viable seeds with known germination techniques.

Putative causes driving low seed quality in TGB species include nutrient-limitation (Fujita et al. 2014), pollen quality (Rosbakh et al. 2018), higher genetic load due to accumulation of deleterious somatic mutations over many disturbance cycles (Lamont \& Wiens 2003), harvesting constraints when faced with irregular fruiting phenology, and a combination of these factors. It also remains to be tested to what extent managing fire regimes would create opportunities to improve sourcing seeds from native TGB species where fire-stimulated 
flowering typically results in higher and more synchronous seed production and higher seed quality (Young 2004; Le Stradic et al. 2015b; Wagenius et al. 2020).

Direct seeding for large-scale ecosystem restoration can be a cost-effective technique to reintroduce functionally diverse plant communities (Figure 7). However, it has rarely been implemented in TGB because of the overall low seed quality mentioned above and because native (local) seeds are not available in sufficient quantities. Two pioneering studies tested direct seeding for TGB restoration, but used relatively few grass and forb species compared to local diversity (13 grass species in Waters et al. 2001; 11 grass and three forb species in Sampaio et al. 2019). While these studies are necessary steps towards efficient seeding, more research on seed ecology is urgently needed. Conversely, the high demand for seeds may have positive impacts, including i) involvement of local communities, generating income and the support of livelihoods through the sustainable use of native biodiversity; ii) protection of native ecosystems as seed sources; iii) decreasing conflict between environmental agencies, local communities and companies that need to perform restoration projects (Schmidt et al. 2019b); and iv) greater costeffectiveness associated with greater market demand. Because seeds are currently sourced from wild populations, thresholds of seed collection need to also be determined. Seed provision/supply chains must be supported and regulated, for which preliminary law and market analysis research are necessary (Urzedo et al. 2019). Although harvesting seeds from perennial species tends to have low impacts on adult plants and populations (Franco \& Silvertown 2004), clear harvesting guidelines are needed to avoid or minimize negative impacts to plant populations, especially 
when these are conservation targets. Economic stimulus for the development of seed farming production can alleviate shortfalls in seed supply, improving the reliability and cost of seeds available for restoration and attenuating the potential for overharvesting of wild plant populations. Seed farming should address evolutionary selection and loss of genetic diversity (Broadhurst et al. 2008, 2015; Nevill et al. 2016). However, this also implies in the development of Seed Transfer Zones, as already developed for some temperate regions, e.g. in Germany (Durka et al. 2017). Given the large knowledge gaps on TGB composition and regional differentiation, the development of ecologically meaningful transfer zones will still require considerable research efforts for most regions.

\section{Reintroducing native species by vegetative propagation and container stock}

A large proportion of plant species from TGB have at least one of the above- mentioned traits that limit propagation from seeds. Therefore, the opportunities for their reintroduction and propagation via seed sowing, soil transfer, and hay transfer, are currently often limited for restoring TGB biodiversity (Le Stradic et al. 2015b; Kolb et al. 2016; Dayrell et al. 2016; Pilon et al. 2018). To be reintroduced, such species may depend mainly on vegetative propagation. Cerrado grassland restoration has proven to be successful at a small scale by transplanting grass tussocks when there are sources available (Pilon et al. 2019). However, for most TGB the transplantation of forbs, subshrubs and shrubs, sometimes even grasses (Le Stradic 2012), is not 
a promising technique. Alternative techniques must then be developed or applied, such as: transplantation of individual tillers grown in pots from fragmented tufts (du Toit 2009), transplantation of seed-germinated pot-grown grasses (Oliveira et al. 2020), cuttings (du Toit 2009; Martins et al. 2015), propagation from bulbs (S. Le Stradic, Technische Universität München, Germany) or roots (Silva et al. 2011), and micropropagation (Biondo et al. 2007; Oliveira et al. 2011; Souza et al. 2015), among others (Figure 8).

While vegetative propagation has been widely used for forestry and orcharding worldwide, it has rarely been mentioned in the context of ecological restoration, and its application at large scales relies on research and technological development, while assuring high genetic variability. Protocols for the reintroduction of TGB species from direct rescue transplantation, or plug production from cuttings, division, scarce seed quantities, or by micropropagation are needed (Koch 2007). Development of propagation protocols should take advantage of the underground storage organs and bud banks which are reliable sources of regeneration in TGB species (Fidelis et al. 2014), and which hold the promise of simultaneously increasing vegetation resilience and providing ecosystem services (Pausas et al. 2018). Most likely, solutions for successful TGB restoration will be based on a mix of different approaches including vegetative propagation, direct seeding and container stock. Examining the costs and benefits of each approach will depend on restoration goals and the socio-ecological context of each grassland. 


\section{Maximizing plant establishment and ecosystem sustainability}

Poor seedling establishment in TGB is often related to seed quality (see above), competition from undesirable species, severe environmental filters acting upon seedling survival, or a combination of these. Research needs to focus on improving i) restoration treatments to maximize species establishment; and ii) subsequent long-term management promoting ecosystem functioning and sustainability.

\section{Maximizing target species establishment}

Controlling invasive herbaceous species (including intentionally introduced forage species), and invasive or native tree and shrub encroachment is a major restoration step to reduce competition from undesirable species. Numerous techniques are available including cutting, removal, grazing, prescribed fires (Figure 9), herbicide application, or, as mentioned in section "Developing techniques to restore soil conditions", deep plowing or topsoil removal if the site is already highly degraded (Buisson et al. 2019). The most suitable combination of treatments is, however, yet to be determined for each TGB type and for each invasive species.

Many TGB are maintained by specific fire regimes and grazing (Veldman et al. 2015). While reintroduction of fire or grazing regimes too early may hamper the establishment of reintroduced species, excluding them for excessive periods decreases diversity, promotes woody 
encroachment and biological invasion, and increases the danger of wildfire occurrence, all of which damage the system (Stevens et al. 2017; Alvarado et al. 2018; Fidelis et al. 2018). Therefore, the appropriate disturbance regime and optimum treatments to keep a balance between the establishment of native and invasive species is yet to be determined through longterm field experiments in both disturbance-dependent and edaphic TGB (sensu Buisson et al. 2019).

Community assembly in old-growth grasslands occurs at large temporal scales (Nerlekar \& Veldman 2020), so pioneer or faster-growing species which are typically used in the early stages of forest or temperate grassland restoration (Silveira et al. online early) are either unknown, or are unsuitable for TGB restoration. Some studies identify and employ fastergrowing, short-lived species to cover the ground and later allow the establishment of long-lived perennial species (e.g. Coutinho et al. 2019). However, these species might not guarantee the resilience of the system because they may actually inhibit the subsequent establishment of perennial species (Nerlekar \& Veldman 2020). While introducing pioneer species could be useful in areas where invasive species and soil erosion are major issues, the ability of this practice to promote high biodiversity in the long-term remains to be demonstrated. Alternatively, restoring small, slow-growing species to facilitate colonization by other native species, and to thus increase native species richness can be a feasible strategy (Fynn et al. 2009). TGB restoration may benefit from trait-based approaches for grasses and forbs to address the 
functional role of herbaceous species in promoting community re-assembly (Silveira et al. online early).

We also need a better understanding of feedbacks between vegetation, fauna, soil microbiota and soil properties (Suding et al. 2004). Mycorrhiza, soil microbes (Lugo \& Pagano 2019), ants (Parr et al. 2016), large herbivores, including livestock (Veblen 2012; Hempson et al. 2015; Fritz 2017), and nurse plants (Gómez-Aparicio 2009) have been shown to play important roles in enhancing target species establishment and persistence, but we still lack proper identification of key ecological engineers with the potential to maximize plant establishment in most TGB. Examining the role of microorganisms in the establishment of TGB species is worthy given recent evidence that restoration outcomes can be improved by reintroducing mycorrhizal fungi from the native plant microbiome in temperate grassy ecosystems (Koziol et al. 2018).

Maximizing ecosystem sustainability (long-term management)

When restoration goals include achieving a sustainable ecosystem, this means ensuring that i) degradation forces remain excluded; ii) introduced plants persist in the long-term; iii) additional native species can establish and successfully reproduce; and iv) restored ecological processes maintain ecosystem functioning (Miller et al. 2017). In disturbance-dependent TGB, wildfires and large herbivores play underappreciated roles not only in restoration (see section "Maximize 
species establishment"), but also in maintaining long-term sustainability and resilience (Asner et al. 2009; Burkepile et al. 2013; Riginos et al. 2018).

Maintaining an appropriate level of herbivory may entail either of two very different groups of large mammalian herbivores: native herbivores and domestic livestock (Figure 10). Native herbivores (and perhaps livestock, see below) not only have an important role in shaping TGB vegetation species composition and structural diversity via their foraging, but also for distributing and maintaining nutrient inputs via dung deposits (Fornara \& Du Toit 2008; Asner et al. 2009; Sitters et al. 2020). Thus, addressing restoration of diverse native herbivore assemblages (refaunation; Seddon et al. 2014) to target sites may be critical to achieving sustainable TGB goals.

Domestic livestock in TGB are represented by a diverse set of species (cattle, sheep, goats, camels, donkeys) that, like wildlife, differ in dietary preferences and ecosystem impacts. Livestock is often the underlying cause of ecosystem degradation, through inappropriately high stocking densities. However, at moderate densities, it may effectively replace native diverse herbivore communities (Veblen et al. 2016; Sitters et al. 2020). This may be especially important in TGB where the native megafauna has been lost and cannot be reintroduced or where prescribed fires are not permitted. Yet, the social and economic forces that led to overgrazing are often still in place, and not easy to shift (Kimiti et al. 2017). Specific studies thus need to determine appropriate overall grazing rates, and spatial and temporal patterns that allow the maintenance of habitat heterogeneity and biodiversity. Studying which levels or combinations of 
domestic and wild native herbivore grazing are appropriate is an essential issue to allow restoration and sustainable use of TGB (Riginos et al. 2012).

Many TGB are maintained by fire (Bond 2019), suggesting that fire management may be needed for restoration (but see edaphic grasslands; Buisson et al. 2019). However, understanding natural fire regimes is challenging because of entrenched anthropogenic fire regimes often preventing an accurate assessment of natural fire frequency, timing, and patterns (Archibald et al. 2013; Johansson et al. 2020; Figure 11). Maintaining a mosaic of diverse fire regimes may be a way to maintain landscape heterogeneity and diversity, but application of specific fire regimes in support of restoration should be further studied (Bond 2019). Fires have declined worldwide in recent decades (Andela et al. 2017), but intentional fires for grassland management are still common in parts of South America (Eloy et al. 2019; Schmidt \& Eloy 2020) and Madagascar (Alvarado et al. 2018) and eastern and southern Africa (Archibald 2016). Even there, increased grazing and bush encroachment (both of which reduce grass fuels) have locally decreased burning (Archibald 2016). In Kenya, grassland fires have become rare (Archibald 2016) both because of heavy grazing in communal rangelands and because private range managers are increasingly disinclined to burn livestock forage (R. Sensenig, Goshen College, IN, personal communication). In the latter case, fire reintroduction may require stakeholder outreach or environmental sociology studies. The strong synergistic effects of fire and herbivory, which can make the combination a far more powerful force than either alone (Midgley et al. 2010; Werner et al. in press) have been investigated for woody plants (Staver et al. 2009; Pringle et al. 2015), 
but remain understudied for the herbaceous component of TGB (but see Burkepile et al. 2016; Smith et al. 2016).

\section{Monitoring}

Monitoring is essential to evaluate restoration success and is particularly important for restored disturbance-dependent ecosystems that require long-term adaptive management (Holl \& Cairns 2002). While monitoring indicators such as tree cover, aboveground biomass and species richness may be appropriate for forest restoration, this alone is not sufficient to determine TGB health (Silveira et al. online early). The suite of indicators to be monitored depends on the restoration goals (Holl \& Cairns. 2002) and on clear definitions of the expected attributes of the desirable ecosystem. This should be better explored for TGB. Candidate indicators for TGB monitoring can be general, such as ground cover or species richness, above and belowground biomass, proportion between different life-forms, fidelity to reference community, abundance of indicator species, among others, but should also include indicators specific to degradation and resilience to disturbance, such as recovery after fire, drought or herbivory, presence and cover by ruderals and exotic species, soil erosion rates, soil compaction or woody encroachment.

Ecosystem functioning is easily affected by changes in the suite of functional traits present. Monitoring native TGB species richness alone may infer that a TGB has been restored adequately, although functional richness, and hence redundancy, may have collapsed, which will 
negatively affect the resilience of the restored ecosystem over time. Monitoring of functional diversity in TGB is therefore imperative to properly evaluate restoration success, providing that the traits to be assessed have been shown to be relevant to TGB functioning and their ecosystem services. Research aimed at developing indicators of TGB functioning should identify easy-tomeasure surrogates for ecosystem attributes and processes that are difficult to assess (Dale \& Beyeler 2001; Prach et al. 2019). Because a number of ecological processes (e.g. regeneration, succession and landscape-level connectivity) operate differently in open ecosystems than they do in forests (Bond 2019, Silveira et al. online early), monitoring TGB restoration is likely to span comparatively larger time frames than in forest restoration. This assumption remains to be tested across a range of TGB.

\section{Conclusion}

The rate of land-use conversion outpaces the rate of scientific knowledge production, posing a great threat to the long-term persistence of TGB and thus calling for collaborative research prioritization. Further, this escalating transformation makes the need for effective restoration initiatives all the more pressing. Here, we have identified emerging questions on ecological dimensions of restoration ecology (Perring et al. 2015) that need to be answered in order to scale up restoration of TGB to meet the challenges of the UN Restoration Decade. Achieving restoration targets for TGB by 2030 seems unlikely because these megadiverse ecosystems do 
not even have a collective name to describe their ecology (Bond 2019), let alone sufficient knowledge to restore them. The set of priorities discussed here are not without bias, but has been assembled by a team of experts facing challenges during TGB restoration for more than two decades. They constitute a first step towards a comprehensive effort to improve the success of TGB restoration worldwide (Figure 1). Providing answers to these questions has the potential to advance theory, practice and policy in TGB restoration (but see Dey et al. 2020), ultimately resulting in long-term benefits to people and nature in some of the most neglected ecosystems of our planet.

\section{Acknowledgments}

EB, AF, AJA, FAOS are supported by CNRS PICS 2018-2020 [RESIGRASS], EB and TPY by France-Berkeley Fund [https://fbf.berkeley.edu/], FAOS, GD, RSO, GEO and AF are supported by grants from CNPq, FAOS by FAPEMIG, TPY by NSF DEB 10-50543 and LTREB 1931224, GEO by Fundação O Boticário, AF by FAPESP (2015/06743-0; 2019/09903-0), RSO by FAPESP-NERC (2019/07773-1), MHS by the Claude Leon Foundation Postdoctoral Fellowship. GEO, AF, GD participate in GrassSyn within the SINBIOSE/CNPq framework (grant 42348/2019-3 to GEO). We thank two anonymous reviewers and Lars Brudvig for their comments, which significantly improved the manuscript. 


\section{References}

Alvarado ST, Silva TSF, Archibald S (2018) Management impacts on fire occurrence: A comparison of fire regimes of African and South American tropical savannas in different protected areas. Journal Environmental Management 218:79-87

Andela N, Morton DC, Giglio L, Chen Y, Werf GR van der, Kasibhatla PS, DeFries RS, Collatz GJ, Hantson S, Kloster S, Bachelet D, Forrest M, Lasslop G, Li F, Mangeon S, Melton JR, Yue C, Randerson JT (2017) A human-driven decline in global burned area. Science 356:1356-1362

Anderegg WRL, Trugman AT, Badgley G, Anderson CM, Bartuska A, Ciais P, Cullenward D, Field CB, Freeman J, Goetz SJ, Hicke JA, Huntzinger D, Jackson RB, Nickerson J, Pacala S, Randerson JT (2020) Climate-driven risks to the climate mitigation potential of forests. Science 368:eaaz7005

Archibald S (2016) Managing the human component of fire regimes: lessons from Africa. Philosophical Transactions of the Royal Society B: Biological Sciences 371:20150346

Archibald S, Lehmann CER, Gómez-Dans JL, Bradstock RA (2013) Defining pyromes and global syndromes of fire regimes. PNAS 110:6442-6447

Asner GP, Levick SR, Kennedy-Bowdoin T, Knapp DE, Emerson R, Jacobson J, Colgan MS, Martin RE (2009) Large-scale impacts of herbivores on the structural diversity of African savannas. PNAS 106:4947-4952 
Bengtsson J, Bullock JM, Egoh B, Everson C, Everson T, O’Connor T, O’Farrell PJ, Smith HG, Lindborg R (2019) Grasslands-more important for ecosystem services than you might think. Ecosphere 10:e02582

Biondo R, Souza AV, Bertoni BW, Soares AM, França SC, Pereira AMS (2007) Micropropagation, seed propagation and germplasm bank of Mandevilla velutina (Mart.) Woodson. Scientia Agricola 64:263-268

Bond WJ (2019) Open Ecosystems: ecology and evolution beyond the forest edge. Oxford University Press, Oxford, New York

Bond WJ, Midgley JJ (2001) Ecology of sprouting in woody plants: the persistence niche. TREE $16: 45-51$

Brancalion PHS, Niamir A, Broadbent E, Crouzeilles R, Barros FSM, Zambrano AMA, Baccini A, Aronson J, Goetz S, Reid JL, Strassburg BBN, Wilson S, Chazdon RL (2019) Global restoration opportunities in tropical rainforest landscapes. Scientific Advance 5:eaav3223

Broadhurst LM, Lowe A, Coates DJ, Cunningham SA, McDonald M, Vesk PA, Yates C (2008) Seed supply for broadscale restoration: maximizing evolutionary potential. Evolutionary Applications 1:587-597

Broadhurst L, Hopley T, Li L, Begley J (2015) Using seed production areas to meet restoration targets and secure genetic diversity. Journal of the Australian Network for Plant Conservation 23:7

Bronick CJ, Lal R (2005) Soil structure and management: a review. Geoderma 124:3-22 
Buisson E, Stradic SL, Silveira FAO, Durigan G, Overbeck GE, Fidelis A, Fernandes GW, Bond WJ, Hermann J-M, Mahy G, Alvarado ST, Zaloumis NP, Veldman JW (2019) Resilience and restoration of tropical and subtropical grasslands, savannas, and grassy woodlands. Biological Reviews 94:590-609

Burkepile DE, Thompson DI, Fynn RWS, Koerner SE, Eby S, Govender N, Hagenah N, Lemoine NP, Matchett KJ, Wilcox KR, Collins SL, Kirkman KP, Knapp AK, Smith MD (2016) Fire frequency drives habitat selection by a diverse herbivore guild impacting topdown control of plant communities in an African savanna. Oikos 125:1636-1646

Burkepile DE, Burns CE, Tambling CJ, Amendola E, Buis GM, Govender N, Nelson V, Thompson DI, Zinn AD, Smith MD (2013) Habitat selection by large herbivores in a southern African savanna: the relative roles of bottom-up and top-down forces. Ecosphere 4:art139

CBD - Convention on Biological Diversity (2011) Aichi Biodiversity Targets. https://www.cbd.int/sp/targets/. Accessed 14 Oct 2019

Climate Summit (2014) Forests - Action Statements and Action Plans. United Nations - Climate Change, New York

Cooke SJ, Bennett JR, Jones HP (2019) We have a long way to go if we want to realize the promise of the "Decade on Ecosystem Restoration.” Conservation Science and Practice $1: \mathrm{e} 129$ 
Coutinho AG, Alves M, Sampaio AB, Schmidt IB, Vieira DLM (2019) Effects of initial functional-group composition on assembly trajectory in savanna restoration. Applied Vegetation Science 22:61-70

Dairel M, Fidelis A (online early) How does fire affect germination of grasses in the Cerrado? Seed Science Research 1-9

Dale VH, Beyeler SC (2001) Challenges in the development and use of ecological indicators. Ecological Indicators 1:3-10

Dayrell RLC, Arruda AJ, Buisson E, Silveira FAO (2016) Overcoming challenges on using native seeds for restoration of megadiverse resource-poor environments: a reply to Madsen et al. Restoration Ecology 24:710-713

Dayrell RLC, Garcia QS, Negreiros D, Baskin CC, Baskin JM, Silveira FAO (2017) Phylogeny strongly drives seed dormancy and quality in a climatically buffered hotspot for plant endemism. Annals of Botany 119:267-277

De Groot RS, Blignaut J, Ploeg SVD, Aronson J, Elmqvist T, Farley J (2013) Benefits of investing in ecosystem restoration. Conservation Biology 27:1286-1293

Dey CJ, Rego AI, Midwood JD, Koops MA (2020) A review and meta-analysis of collaborative research prioritization studies in ecology, biodiversity conservation and environmental science. Proceedings of the Royal Society B: Biological Sciences 287:20200012 
du Toit JCO (2009) Early survival and growth of vegetatively propagated indigenous grasses in a clear-felled timber plantation in KwaZulu-Natal, South Africa. African Journal of Range \& Forage Science 26: 97-101

Dubayah R, Blair JB, Goetz S, Fatoyinbo L, Hansen M, Healey S, Hofton M, Hurtt G, Kellner J, Luthcke S, Armston J, Tang H, Duncanson L, Hancock S, Jantz P, Marselis S, Patterson PL, Qi W, Silva C (2020) The global ecosystem dynamics investigation: High-resolution laser ranging of the Earth’s forests and topography. Science of Remote Sensing 1:100002

Durka W, Michalski SG, Berendzen KW, Bossdorf O, Bucharova A, Hermann J-M, Hölzel N, Kollmann J (2017) Genetic differentiation within multiple common grassland plants supports seed transfer zones for ecological restoration. Journal of Applied Ecology 54:116-126

Ehrenfeld JG (2000) Defining the limits of restoration: the need for realistic goals. Restoration Ecology 8:2-9

Eloy L, Schmidt IB, Borges SL, Ferreira MC, dos Santos TA (2019) Seasonal fire management by traditional cattle ranchers prevents the spread of wildfire in the Brazilian Cerrado. Ambio 48:890-899

Fagan ME (2020) A lesson unlearned? Underestimating tree cover in drylands biases global restoration maps. Global Change Biology 26:4679-4690

Fidelis A, Alvarado ST, Barradas ACS, Pivello VR (2018) The Year 2017: Megafires and Management in the Cerrado. Fire 1:49 
Fidelis A, Appezzato-da-Glória B, Pillar VD, Pfadenhauer J (2014) Does disturbance affect bud bank size and belowground structures diversity in Brazilian subtropical grasslands? Flora Morphol Distrib Funct Ecol Plants 209:110-116

Fornara DA, Du Toit JT (2008) Browsing-induced effects on leaf litter quality and decomposition in a Southern African savanna. Ecosystems 11:238-249

Franco M, Silvertown J (2004) A comparative demography of plants based upon elasticities of vital rates. Ecology 85:531-538

Fritz H (2017) Long-term field studies of elephants: understanding the ecology and conservation of a long-lived ecosystem engineer. Journal of Mammalogy 98:603-611

Fujita Y, Venterink HO, Bodegom PM van, Douma JC, Heil GW, Hölzel N, Jabłońska E, Kotowski W, Okruszko T, Pawlikowski P, Ruiter PC de, Wassen MJ (2014) Low investment in sexual reproduction threatens plants adapted to phosphorus limitation. Nature 505:82-86

Fynn RW, Wragg PD, Morris CD, Kirkman KP, Naiken J (2009) Vegetative traits predict grass species' invasiveness and the invasibility of restored grassland. African Journal Range Forage Science 26:59-68

Gann GD, McDonald T, Walder B, Aronson J, Nelson CR, Jonson J, Hallett JG, Eisenberg C, Guariguata MR, Liu J, Hua F, Echeverría C, Gonzales E, Shaw N, Decleer K, Dixon KW (2019) International principles and standards for the practice of ecological restoration. Second edition. Restoration Ecology 27:S1-S46 
Gómez-Aparicio L (2009) The role of plant interactions in the restoration of degraded ecosystems: a meta-analysis across life-forms and ecosystems. Journal of Ecology $97: 1202-1214$

Harpole WS, Sullivan LL, Lind EM, Firn J, Adler PB, Borer ET, et al. (2016) Addition of multiple limiting resources reduces grassland diversity. Nature 537:93-96

Hempson GP, Archibald S, Bond, WJ, Ellis RP, Grant CC, Kruger FJ, Kruger LM, Moxley C, Owen-Smith N, Peel MJS, Smit IPJ, Vickers KJ (2015) Ecology of grazing lawns in Africa. Biological Reviews 90:979-994.

Higgs ES, Harris JA, Heger T, Hobbs RJ, Murphy SD, Suding KN (2018) Keep ecological restoration open and flexible. Nature Ecology \& Evolution 2:580-580

Holl KD, Cairns Jr. J (2002) Monitoring and appraisal. In: Perrow MR, Davy AJ (eds) Handbook of restoration ecology - 2. Restoration in practice. Cambridge University Press, Cambridge, UK; New York, pp 411-425

IRP - International Resource Panel (2019) Global Resources Outlook 2019: Natural Resources for the Future We Want. United Nations - Environment Programme, Nairobi, Kenya

IUCN DC (2011) The Bonn Challenge. In: Bonn Chall. http://www.bonnchallenge.org/content/challenge. Accessed 14 Oct 2019

Johansson MU, Abebe FB, Nemomissa S, Bekele T, Hylander K (2020) Ecosystem restoration in fire-managed savanna woodlands: Effects on biodiversity, local livelihoods and fire intensity. Ambio https://doi.org/10.1007/s13280-020-01343-7 
Kimiti DW, Riginos C, Belnap J (2017) Low-cost grass restoration using erosion barriers in a degraded African rangeland. Restoration Ecology 25:376-384

Kinyua D, McGeoch LE, Georgiadis N, Young TP (2010) Short-term and long-term effects of soil ripping, seeding, and fertilization on the restoration of a tropical rangeland. Restoration Ecology 18:226-233

Koch JM (2007) Alcoa's mining and restoration process in South Western Australia. Restoration Ecology 15:S11-S16

Kolb RM, Pilon NAL, Durigan G, Kolb RM, Pilon NAL, Durigan G (2016) Factors influencing seed germination in Cerrado grasses. Acta Botanica Brasilica 30:87-92

Koziol L, Schultz PA, House GL, Bauer JT, Middleton EL, Bever JD. (2018) The plant microbiome and native plant restoration: examples of native mycorrhizal fungi. Bioscience 68: 996-1006.

Ladouceur E, Jiménez-Alfaro B, M arin M, Vitis MD, Abbandonato H, Iannetta PPM, Bonomi C, Pritchard HW (2018) Native seed supply and the restoration species pool. Conservation Letters 11:e12381

Lamont BB, Wiens D (2003) Are seed set and speciation rates always low among species that resprout after fire, and why? Evolutionary Ecology 17:277-292

Le Stradic S (2012) Composition, phenology and restoration of campo rupestre mountain grasslands - Brazil. Ph.D. thesis Universidade Federal de Minas Gerais \& Avignon Université 
Le Stradic S, Buisson E, Fernandes GW (2015a) Baseline data for the conservation of Neotropical mountain grasslands: vegetation composition and structure. Journal of Mountain Science 12:864-877

Le Stradic S, Silveira FAO, Buisson E, Cazelles K, Carvalho V, Fernandes GW (2015b) Diversity of germination strategies and seed dormancy in herbaceous species of campo rupestre grasslands. Austral Ecology 40:537-546

Lugo MA, Pagano MC (2019) Overview of the Mycorrhizal Fungi in South America. In: Pagano MC, Lugo MA (eds) Mycorrhizal Fungi in South America. Springer International Publishing, Cham, pp 1-27

Martins WA, Mantelli M, Santos SC, Netto APC, Pinto F (2015) Estaquia e concentração de reguladores vegetais no enraizamento de Campomanesia adamantium. Revista de Ciências Agrárias 38:58-64

Meli P, Holl KD, Benayas JMR, Jones HP, Jones PC, Montoya D, Mateos DM (2017) A global review of past land use, climate, and active vs. passive restoration effects on forest recovery. PLoS One 12:e0171368

Midgley JJ, Lawes MJ, Chamaillé-Jammes S (2010) Savanna woody plant dynamics: the role of fire and herbivory, separately and synergistically. Australian Journal of Botany 58:1-11

Miller BP, Sinclair EA, Menz MHM, Elliott CP, Bunn E, Commander LE, Dalziell E, David E, Davis B, Erickson TE, Golos PJ, Krauss SL, Lewandrowski W, Mayence CE, MerinoMartín L, Merritt DJ, Nevill PG, Phillips RD, Ritchie AL, Ruoss S, Stevens JC (2017) A 
framework for the practical science necessary to restore sustainable, resilient, and biodiverse ecosystems. Restoration Ecology 25:605-617

Morecroft MD, Duffield S, Harley M, Pearce-Higgins JW, Stevens N, Watts O, Whitaker J (2019). Measuring the success of climate change adaptation and mitigation in terrestrial ecosystems. Science 366:9256

Nerlekar AN, Veldman JW (2020) High plant diversity and slow assembly of old-growth grasslands PNAS 117:18550-18556

Nevill PG, Tomlinson S, Elliott CP, Espeland EK, Dixon KW, Merritt DJ (2016) Seed production areas for the global restoration challenge. Ecology and Evolution 6:7490-7497

Oliveira ACC de, Forti VA, Loiola P de P, Viani RAG (2020) Techniques for seedling production of two native grasses: new perspectives for Brazilian Cerrado restoration. Restoration Ecology 28:297-303

Oliveira TG de, Pina PSS, Bertoni BW, França S de C, Pereira AMS (2011) Micropropagação de Croton antisyphiliticus Mart. Ciência Rural 41:1712-1718

Overbeck GE, Vélez-Martin E, Scarano FR, Lewinsohn TM, Fonseca CR, Meyer ST, Müller SC, Ceotto P, Dadalt L, Durigan G, Ganade G, Gossner MM, Guadagnin DL, Lorenzen K, Jacobi CM, Weisser WW, Pillar VD (2015) Conservation in Brazil needs to include nonforest ecosystems. Diversity and Distribution 21:1455-1460 
Parr CL, Eggleton P, Davies AB, Evans TA, Holdsworth S (2016) Suppression of savanna ants alters invertebrate composition and influences key ecosystem processes. Ecology 97:16111617

Parr CL, Lehmann CER, Bond WJ, Hoffmann WA, Andersen AN (2014) Tropical grassy biomes: misunderstood, neglected, and under threat. Trends in Ecology and Evolution 29:205-213

Pausas JG, Lamont BB, Paula S, Appezzato-da-Glória B, Fidelis A (2018) Unearthing belowground bud banks in fire-prone ecosystems. New Phytologist 217:1435-1448

Perring MP, Standish RJ, Price JN, Craig MD, Erickson TE, Ruthrof KX, Whiteley AS, Valentine LE, Hobbs RJ (2015) Advances in restoration ecology: rising to the challenges of the coming decades. Ecosphere 6:art131

Pilon NAL, Assis GB, Souza FM, Durigan G (2019) Native remnants can be sources of plants and topsoil to restore dry and wet cerrado grasslands. Restoration Ecology 27:569-580

Pilon NAL, Buisson E, Durigan G (2018) Restoring Brazilian savanna ground layer vegetation by topsoil and hay transfer. Restoration Ecology 26:73-81

Plante AF, McGill WB (2002) Soil aggregate dynamics and the retention of organic matter in laboratory-incubated soil with differing simulated tillage frequencies. Soil Tillage Reseach 66:79-92

Ploton P, Mortier F, Réjou-Méchain M, Barbier N, Picard N, Rossi V, Dormann C, Cornu G, Viennois G, Bayol N, Lyapustin A, Gourlet-Fleury S, Pélissier R (2020) Spatial validation 
reveals poor predictive performance of large-scale ecological mapping models. Nature Communications 11:4540

Prach K, Durigan G, Fennessy S, Overbeck GE, Torezan JM, Murphy SD (2019) A primer on choosing goals and indicators to evaluate ecological restoration success. Restoration Ecology 27:917-923

Pringle RM, Kimuyu DM, Sensenig RL, Palmer TM, Riginos C, Veblen KE, Young TP (2015) Synergistic effects of fire and elephants on arboreal animals in an African savanna. Journal of Animal Ecology 84:1637-1645

Riginos C, Porensky LM, Veblen KE, Odadi WO, Sensenig RL, Kimuyu D, Keesing F, Wilkerson ML, Young TP (2012) Lessons on the relationship between livestock husbandry and biodiversity from the Kenya Long-term Exclosure Experiment (KLEE). Pastoralism: Research, Policy and Practice 2:10

Riginos C, Porensky LM, Veblen KE, Young TP (2018) Herbivory and drought generate shortterm stochasticity and long-term stability in a savanna understory community. Ecological Applications 28:323-335

Rosbakh S, Pacini E, Nepi M, Poschlod P (2018) An unexplored side of regeneration niche: Seed quantity and quality are determined by the effect of temperature on pollen performance. Frontiers in Plant Science 9

Rusdy M (2017) A review on hardseedness and breaking dormancy in tropical forage legumes. Livestock Research for Rural Development 29(12):237 
Sampaio AB, Vieira DLM, Holl KD, Pellizzaro KF, Alves M, Coutinho AG, Cordeiro A, Ribeiro JF, Schmidt IB (2019) Lessons on direct seeding to restore Neotropical savanna. Ecological Engineering 138:148-154

Sankaran M, Hanan NP, Scholes RJ, Ratnam J, Augustine DJ, Cade BS, Gignoux J, Higgins SI, Le Roux X, Ludwig F, Ardo J, Banyikwa F, Bronn A, Bucini G, Caylor KK, Coughenour MB, Diouf A, Ekaya W, Feral CJ, February EC, Frost PGH, Hiernaux P, Hrabar H, Metzger KL, Prins HHT, Ringrose S, Sea W, Tews J, Worden J, Zambatis N (2005) Determinants of woody cover in African savannas. Nature 438:846-849

Schmidt IB, Eloy L (2020) Fire regime in the Brazilian Savanna: Recent changes, policy and management. Flora Morphol. Distrib. Funct. Ecol. Plants 268:151613

Schmidt IB, Ferreira MC, Sampaio AB, Walter BMT, Vieira DLM, Holl KD (2019a) Tailoring restoration interventions to the grassland-savanna-forest complex in central Brazil. Restoration Ecology 27:942-948

Schmidt IB, Urzedo DI de, Piña-Rodrigues FCM, Vieira DLM, Rezende GM de, Sampaio AB, Junqueira RGP (2019b) Community-based native seed production for restoration in Brazil - the role of science and policy. Plant Biology 21:389-397

Seddon PJ, Griffiths CJ, Soorae PS, Armstrong DP (2014) Reversing defaunation: Restoring species in a changing world. Science 345:406-412 
Silva DB, Vieira RF, Cordeiro MCT, Pereira EBC, Pereira AV (2011) Propagação vegetativa de Brosimum gaudichaudii Tréc. (mama-cadela) por estacas de raízes. Revista Brasileira de Plantas Medicinais 13:151-156

Silveira FAO, Arruda AJ, Bond W, Durigan G, Fidelis A, Kirkman K, Oliveira RS, Overbeck GE, Sansevero JBB, Siebert F, Siebert SJ, Young TP, Buisson E (online early) Mythbusting tropical grassy biome restoration. Restoration Ecology

Sitters J, Kimuyu DM, Young TP, Claeys P, Venterink HO (2020) Megaherbivores reverse negative effects of cattle on soil carbon and nutrient pools. Nature Sustainability 3:360-366

Smith MD, Knapp AK, Collins SL, Burkepile DE, Kirkman KP, Koerner SE, Thompson DI, Blair JM, Burns CE, Eby S, Forrestel EJ, Fynn RWS, Govender N, Hagenah N, Hoover DL, Wilcox KR (2016) Shared drivers but divergent ecological dynamics: insights from long-term experiments in savanna grasslands. Bioscience 66:666-682

Souza AV de, Oliveira FJV, Bertoni BW, França SC, Pereira AMS (2015) Enraizamento in vitro de catuaba (Anemopaegma arvense (Vell.) Stell. ex de Souza), uma planta medicinal do Cerrado. Revista Brasileira de Plantas Medicinais 17:51-58

Staver AC, Bond WJ, Stock WD, van Rensburg SJ, Waldram MS (2009) Browsing and fire interact to suppress tree density in an African savanna. Ecological Applications 19:19091919.

Stevens N, Lehmann CER, Murphy BP, Durigan G (2017) Savanna woody encroachment is widespread across three continents. Global Change Biology 23:235-244 
Suding KN, Gross KL, Houseman GR (2004) Alternative states and positive feedbakcs in restoration ecology. Trends in Ecology and Evolution 19:46-53

Temperton VM, Buchmann N, Buisson E, Durigan G, Kazmierczak Ł, Perring MP, Dechoum M de S, Veldman JW, Overbeck GE (2019) Step back from the forest and step up to the Bonn Challenge: how a broad ecological perspective can promote successful landscape restoration. Restoration Ecology 27:705-719

Tölgyesi C, Török P, Hábenczyus AA, Bátori Z, Valkó O, Deák B, Tóthmérész B, Erdős L, Kelemen A (2020) Underground deserts below fertility islands? Woody species desiccate lower soil layers in sandy drylands. Ecography 43:848-859

UN Environment Programme (2019) New UN Decade on Ecosystem Restoration offers unparalleled opportunity for job creation, food security and addressing climate change. In: UNEP - UN Environ. Programme. http://www.unenvironment.org/news-and-stories/pressrelease/new-un-decade-ecosystem-restoration-offers-unparalleled-opportunity. Accessed 14 Oct 2019

Urzedo DI de, Fisher R, Piña-Rodrigues FCM, Freire JM, Junqueira RGP (2019) How policies constrain native seed supply for restoration in Brazil. Restoration Ecology 27:768-774

Veblen, KE (2012) Savanna glade hotspots: plant community development and synergy with large herbivores. Journal of Arid Environments 78:119-127 
Veblen KE, Porensky LM, Riginos C, Young TP (2016) Are cattle surrogate wildlife? Savanna plant community composition explained by total herbivory more than herbivore type. Ecological Applications 26:1610-1623

Veldman JW (2016) Clarifying the confusion: old-growth savannahs and tropical ecosystem degradation. Philosophical transactions of the Royal Society of London. Series B, Biological sciences 371:20150306

Veldman JW, Aleman JC, Alvarado ST, Anderson TM, Archibald S, Bond WJ, Boutton TW, Buchmann N, Buisson E, Canadell JG, Dechoum M de S, Diaz-Toribio MH, Durigan G, Ewel JJ, Fernandes GW, Fidelis A, Fleischman F, Good SP, Griffith DM, Hermann J-M, Hoffmann WA, Stradic SL, Lehmann CER, Mahy G, Nerlekar AN, Nippert JB, Noss RF, Osborne CP, Overbeck GE, Parr CL, Pausas JG, Pennington RT, Perring MP, Putz FE, Ratnam J, Sankaran M, Schmidt IB, Schmitt CB, Silveira FAO, Staver AC, Stevens N, Still CJ, Strömberg CAE, Temperton VM, Varner JM, Zaloumis NP (2019) Comment on “The global tree restoration potential." Science 366:eaay7976

Veldman JW, Buisson E, Durigan G, Fernandes GW, Le Stradic S, Mahy G, Negreiros D, Overbeck GE, Veldman RG, Zaloumis NP, Putz FE, Bond WJ (2015) Toward an oldgrowth concept for grasslands, savannas, and woodlands. Frontiers in Ecology and the Environment 13:154-162 
Veldman JW, Putz FE (2011) Grass-dominated vegetation, not species-diverse natural savanna, replaces degraded tropical forests on the southern edge of the Amazon Basin. Biological Conservation 144:1419-1429

Veldman JW, Silveira FAO, Fleischman FD, Ascarrunz NL, Durigan G (2017) Grassy biomes: An inconvenient reality for large-scale forest restoration? A comment on the essay by Chazdon and Laestadius. American Journal of Botany 104:649-651

Wagenius S, Beck J, Kiefer G (2020) Fire synchronizes flowering and boosts reproduction in a widespread but declining prairie species. PNAS 117:3000-3005

Waters C, Whalley W, Huxtable C (2001) Grassed up - guidelines for revegetating with Australian native grasses. NSWDPI

Werner CM, LaMalfa E, Sensenig RL, Kimuyu DM, Young TP (in press) Synergistic effects of herbivores and repeat fire on spatial heterogeneity of prescribed burns and their consequences for tree saplings. Ecology (in press)

Young TP (2004) Fire-induced reproduction of Festuca pilgeri in the subalpine zone of Mount Kenya. African Journal Ecology 42:235-236

Zahawi RA, Reid JL, Holl KD (2015) Passive restoration can be an effective strategy: a reply to Prach and del Moral (2015). Restoration Ecology 23:347-348 
Figure 1. We identified emerging questions across broad themes in restoration (left of the figure) to structure questions aimed at optimizing practical restoration outcomes for TGB (Tropical Grassy Biomes, i.e. old-growth tropical and subtropical grasslands and savannas). Research should focus on: disentangling the reasons why TGB are often undervalued and misunderstood; mapping TGB restoration opportunities; identifying and recognizing regions where alternative stable states exist (a - Suding et al. 2004) and recognizing areas with natural regeneration potential to avoid unnecessary intervention; restoring abiotic conditions; disentangling factors driving low seed quality; determining germination requirements and developing vegetative propagation techniques for TGB species; disentangling the limiting factors and key ecological processes underlying seedling establishment and community assembly; improving and validating long-term management to mimic natural disturbance regimes, and improving monitoring.

Figure 2. Pristine TGB are sometimes confused with degraded grasslands: (a) Open savannas in the Cerrado, Parque Estadual do Jalapão, Northern Brazil, composed of a continuous species-rich herbaceous layer and scattered shrubs and small trees; the photo also shows two rhea (Rhea americana), a bird native to these ecosystems (photo credit AF); (b) A former Pinus spp. plantation in the Cerrado after removal of the trees. Melinis minutiflora (purple inflorescence), an African grass, has invaded the system, outcompeting native grasses and forbs (photo credit AF); (c) Native grassland in Serra dos Carajás, Pará, Brazil (photo credit AJA); (d) Derived grassland replacing former forest in Carajás National Forest, Pará, Brazil (photo credit AJA); (e) 
Open Acacia savanna, with a continuous herbaceous layer and scattered trees and shrubs, during the wet season in Kruger National Park, South Africa; the photo also shows ostriches (Struthio camelus), which are native to these systems (photo credit DT); (f) Open Acacia savanna during the dry season, Kruger National Park, South Africa (photo credit DT).

Figure 3. In many regions, grass-dominated ecosystems have existed historically as alternative states in mosaics alongside woody vegetation types, often forming a continuum from grassland and savanna to closed-canopy woodland and forest in relation to different disturbance regimes and/or environmental gradients; (a) Grassland, (b) Savanna, (c) Cerradão, a woodland, all from the Itirapina Ecological Station, Brazil (photo credit GD); (d) Grassland-Protea savanna continuum in Marakele National Park, Waterberg, South Africa (photo credit DT). Grassland or savanna and forest can also represent alternative stable states in the landscape; (e) Grassland and dense savanna in Mole National Park, Ghana (photo credit GD); (f) Mosaic of grassland and savanna in Magaliesberg, South Africa. Mosaics of grassy and woody vegetation can also represent patterns due to edaphic factors (photo credit SJS); (g) Grasslands and rocky outcrops in Swaziland (photo credit SJS); (h) Grassland-forest alternative stable states, here maintained by edaphic factors in the Soutpansberg, South Africa (photo credit DT); (i) Mosaic of grassland, savanna and forest in the Katanga copperbelt, Democratic Republic of Congo (photo credit copperflora.org); (j) Stony and sandy grasslands, as well as rocky outcrops, in Serra do Cipo, Brazil (photo credit EB). 
Figure 4. Large-scale earthwork often constitutes the first step in post-mining restoration. In the Katanga copperbelt, Democratic Republic of Congo, various grassland communities occur on outcrops depending on a gradient of copper $(\mathrm{Cu})$ and cobalt $(\mathrm{Co})$ concentrations. The image shows a post-mining restoration site where a hill was re-shaped to create the template for restored grassland communities. The hill comprises relatively high $\mathrm{Cu}-\mathrm{Co}$ concentration subsoil. A small area of high Cu-Co concentration topsoil was spread on which vegetation has already established (photo credit S Le Stradic, Technische Universität München, Germany).

Figure 5. Soil preparation may be the first step in restoration: (a) Ripping allows the breaking up of sealed soil surfaces, leading to natural recruitment by Cynodon sp., Kenya (photo credit TPY); (b) Soil plowing before direct seeding in Chapada dos Veadeiros National Park, Brazil; many TGB species have underground storage organs that confer resilience to endogenous disturbance (Figure 6), so disrupting the soil is advised only if the degradation has already largely destroyed the underground component of the vegetation; benefits and potential negative consequences of soil preparation have seldom been studied (photo credit IS); (c) and (d) Soil preparation for seeding with Themeda triandra in gel, which provides sustained moisture for germination, South Africa (photo credits KK).

Figure 6. Non-graminoid TGB species often have underground storage organs or a bud bank that confers resilience: (a) Commicarpus pentandrus, South Africa (photo credit SJS); (b) 
Gomphrena macrocephala, Itirapina Ecological Station, Brazil (photo credit EB); (c) Crotalaria cornetii, Katanga, Democratic Republic of Congo (photo credit copperflora.org).

Figure 7. (a) Direct sowing of native seeds on an opencast coal mine, South Africa. Seeds were harvested from undisturbed grassland within $20 \mathrm{~km}$ of the rehabilitation site, using hand-held flail harvesters, which collected seeds from all grass and forb species present. Seeds were not separated or sorted, and were air-dried and stored for one year, thereafter they were mixed into a gel and placed in the soil, in the same species ratios as harvested and (b) the same site in South Africa four years later; the dominant grass species established were Eragrostis curvula, Eragrostis racemosa, Melinis repens, Paspalum scrobiculatum, Perotis patens, Pogonarthria squarrosa, and Themeda triandra (photo credit KK); (c) Mechanized direct seeding of grasses, forbs, shrubs and trees in degraded Neotropical savanna in Central Brazil and (d) Broadcast seeding of these same life-forms performed by volunteers in Chapada dos Veadeiros National Park in Central Brazil (photo credits F Tatagiba, ICMBio).

Figure 8. Reintroduction of recalcitrant species may depend mainly on vegetative propagation. Research should focus on propagating TGB plants from stem cuttings, bulbs or roots via micropropagation: (a) Identification of the niche of four populations of Aeollanthus saxatilis and propagation trials from tubers, in Katanga, Democratic Republic of Congo (photo credit 
copperflora.org); (b) In vitro cultivation trial of Rhynchospora consanguinea from campo rupestre grasslands, Cerrado, Brazil (photo credit EB); (c) Large-scale restoration of Cerrado grassland by transplanting, in Santa Bárbara State Forest, Brazil (photo credit GD); and (d) the same site three years after transplanting (photo credit GD).

Figure 9. Prescribed fires can be used to positive effect in the restoration process: (a) Study of the effect of fire to control the invasive African grass Urochloa brizantha (syn. Brachiaria brizantha) invading the Cerrado at the Itirapina Ecological Station, Brazil (photo credit AF); (b) Study of the effect of fire to control the grass Melinis minutiflora invading the Cerrado; the image shows the plant community after a prescribed dry season burn conducted in July 2014 . The photo was taken in October 2015, at the beginning of the rainy season; M. minutiflora has germinated or resprouted, along with some native species (e.g. Eugenia punicifolia at the top of the plot, with some Cyperaceae below, Qualea grandiflora and Pradosia brevipes to the left and right of the plot, respectively, Itirapina Ecological Station, Brazil (photo credit G Damasceno, UNESP Rio Claro); (c) Study of the role of fire in removing pine litter and stimulating native species recovery after degradation of coastal grasslands by tree plantations, Lagoa do Peixe National Park, Rio Grande do Sul, Brazil and (d) Study of the role of fire in removing pine litter and stimulating native species recovery after degradation by tree plantations in highland grasslands in southern Brazil. One year after the experimental burn vegetation is dominated by 
native ruderal sedges from the soil seed bank, while grasses typical of the reference systems did not recruit, indicating the need for active seed introduction (photo credits GEO).

Figure 10. Maintaining an appropriate level of herbivory may entail either of two different groups of large mammalian herbivores, being native herbivores and domestic livestock: (a) Native herbivores and domestic livestock co-existing, Kenya (photo credit RM Pringle, Princeton, NJ); (b) Foraging behaviour and carrying capacities, e.g. for the African elephant Loxodonta africana, must be studied to carefully plan the restoration of diverse herbivore assemblages in savannas such as the Kruger National Park, South Africa (photo credit DT); (c) Understanding the synergistic effects of fire and herbivory on structuring the herbaceous vegetation component is critical in savanna restoration and management. Here, mixed herbivores (giraffe Giraffa camelopardalis and Burchell's zebra Equus quagga burchellii) are excluded from areas of fire-manipulated savanna, Kruger National Park, South Africa (photo credit DT) and (d) blue wildebeest Connochaetes taurinus grazing in and around an exclosure designed to preclude only the largest of the African herbivores (photo credit D Burkepile, University of California Santa Barbara).

Figure 11. Maintaining fire in TGB is important, but the frequency, timing, and pattern of the fire regime must be studied: (a) Fire experiments in wet grasslands in Jalapão, Goáis, Brazil (photo credit AF); (b) Fire team measuring environmental conditions during fire experiments in Reserva 
Natural Serra do Tombador, Tocantins, Brazil (photo credit AF); (c) Early dry season (July) prescribed fire and (d) late dry season (October) prescribed fire, both in Reserva Natural Serra do Tombador, Tocantins, Brazil (photo credit AF); (e) Endangered woodbush granite grassland degraded through encroachment by woody species, Haenertsburg Nature Reserve, South Africa and (f) prescribed fire being used to remove encroaching woody species and restore biodiversity in the same grassland (photo credit DT); (g) Fire frequency experiments have been carried out for over 60 years on experimental plots in the Kruger National Park, South Africa (photo credit D Burkepile, University of California Santa Barbara).

Figure 12. Sampling species diversity and functional traits in pristine TGB reference ecosystems is critical in establishing the benchmark for local restoration goals, Haenertsburg Nature Reserve, South Africa (photo credit DT). 

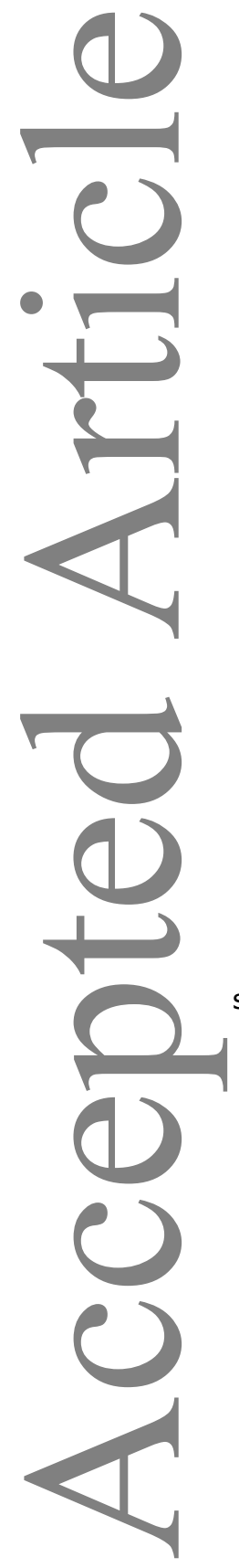

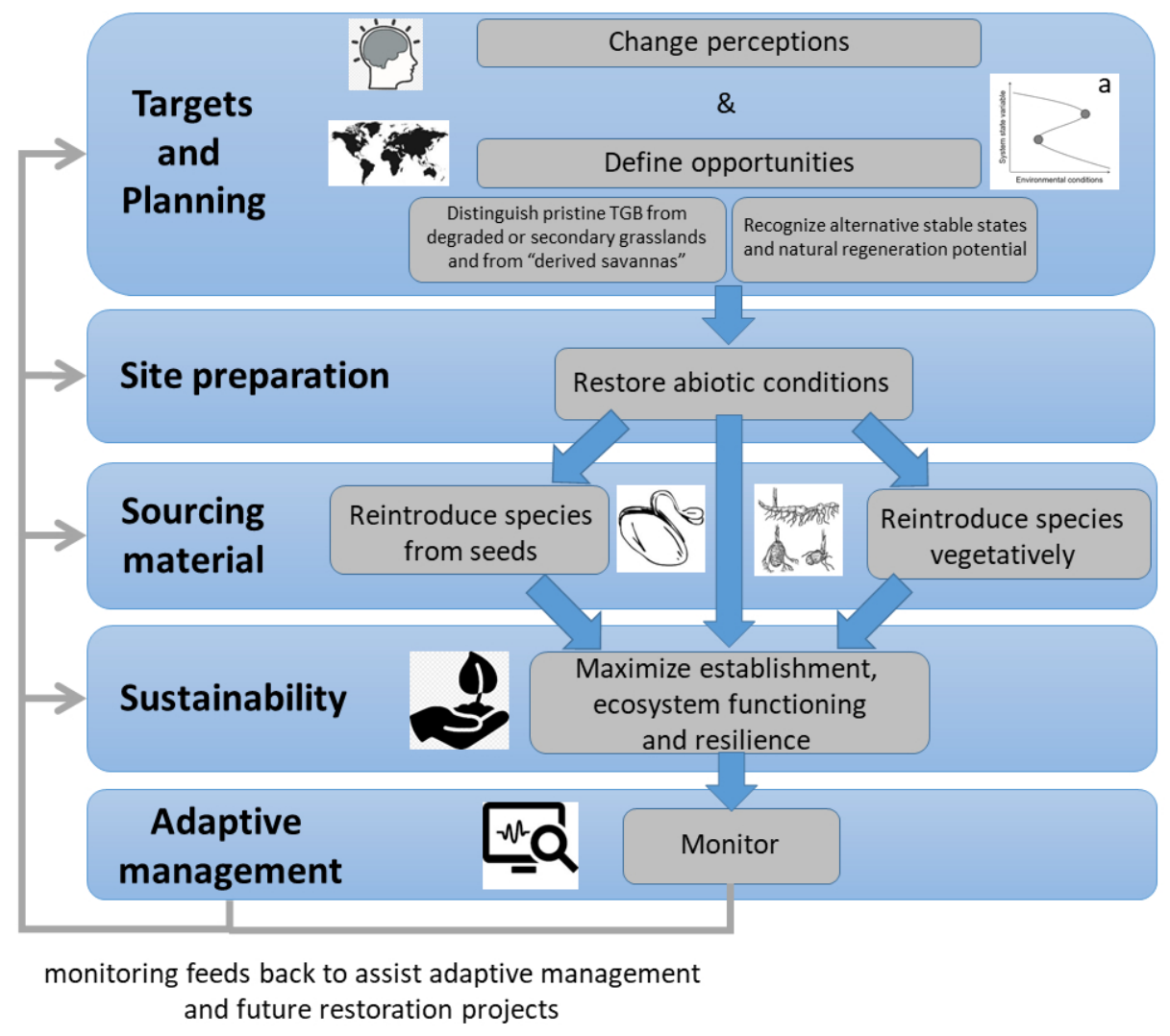

Figure 1. We identified emerging questions across broad themes in restoration (left of the figure) to structure questions aimed at optimizing practical restoration outcomes for TGB (Tropical Grassy Biomes, i.e. old-growth tropical and subtropical grasslands and savannas). Research should focus on: disentangling the reasons why TGB are often undervalued and misunderstood; mapping TGB restoration opportunities; identifying and recognizing regions where alternative stable states exist (a - Suding et al. 2004) and recognizing areas with natural regeneration potential to avoid unnecessary intervention; restoring abiotic conditions; disentangling factors driving low seed quality; determining germination requirements and developing vegetative propagation techniques for TGB species; disentangling the limiting factors and key ecological processes underlying seedling establishment and community assembly; improving and validating long-term management to mimic natural disturbance regimes, and improving monitoring.

$277 \times 239 m m(96 \times 96$ DPI) 

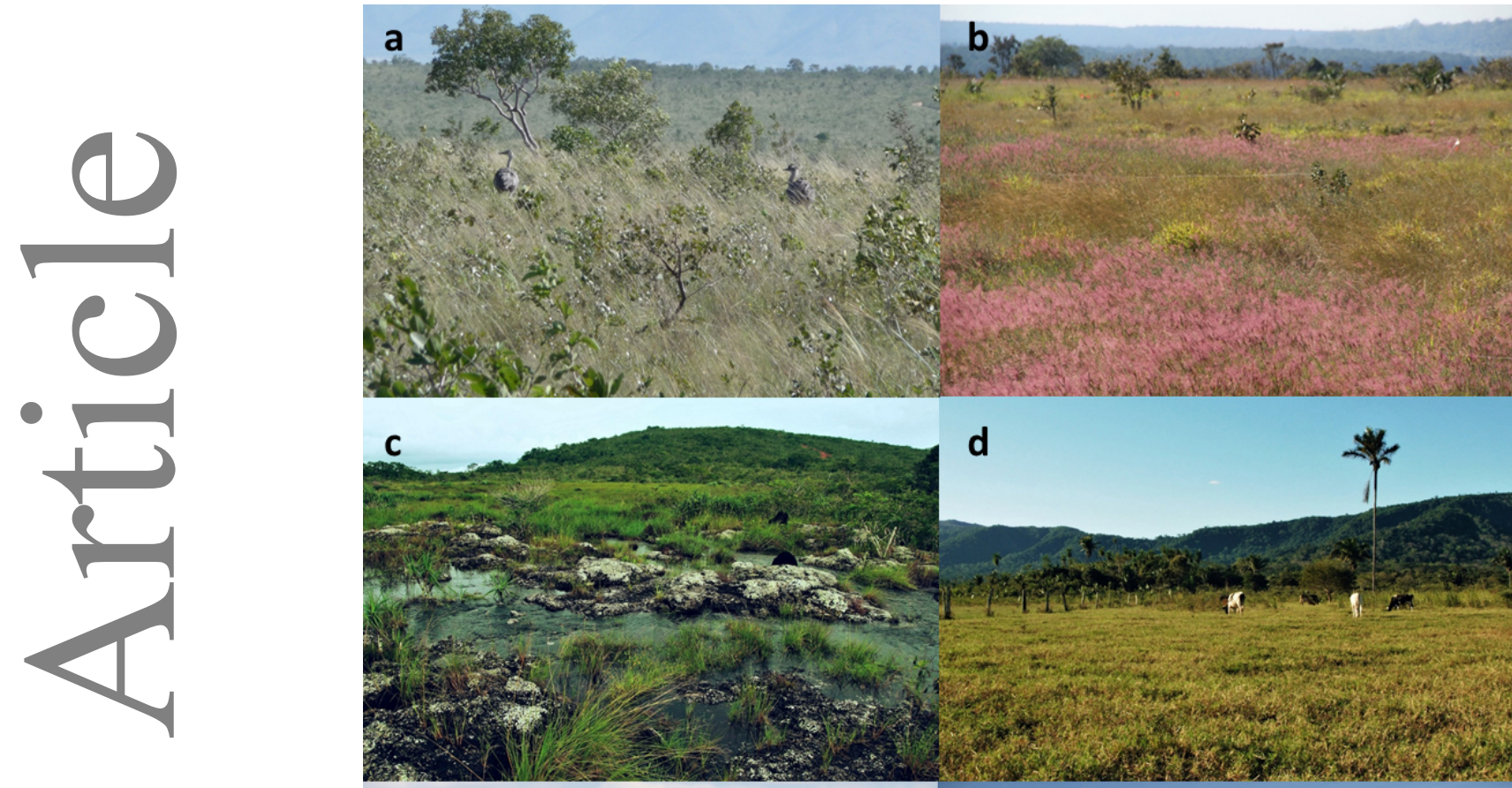

d

e
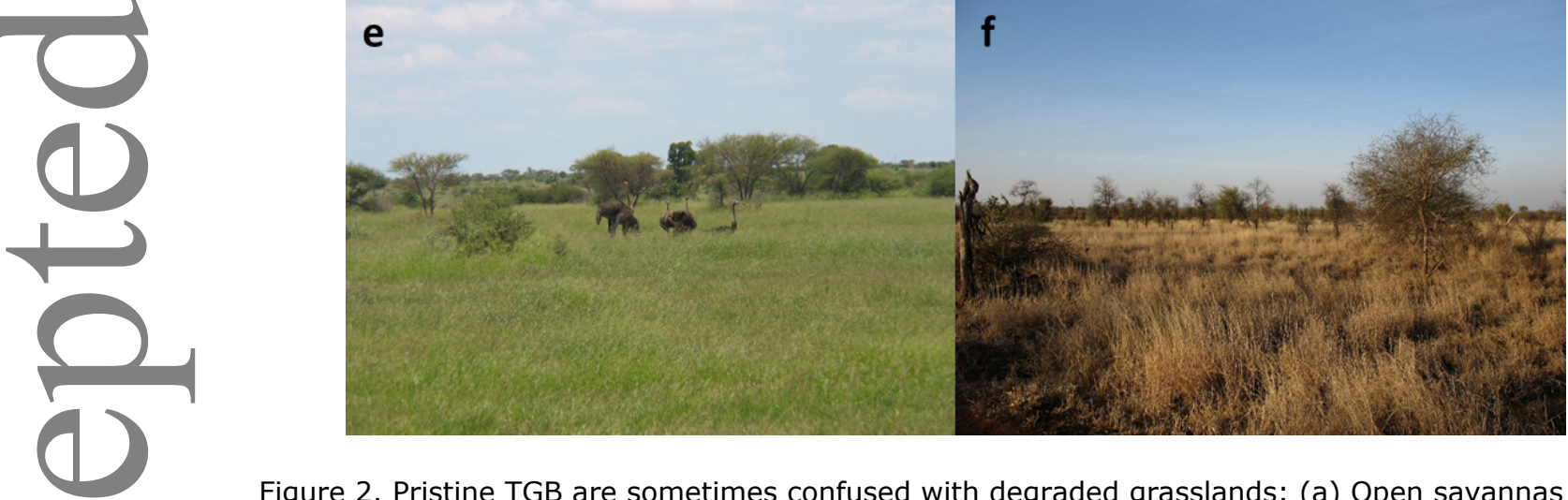

Figure 2. Pristine TGB are sometimes confused with degraded grasslands: (a) Open savannas in the Cerrado, Parque Estadual do Jalapão, Northern Brazil, composed of a continuous species-rich herbaceous layer and scattered shrubs and small trees; the photo also shows two rhea (Rhea americana), a bird native to these ecosystems (photo credit AF); (b) A former Pinus spp. plantation in the Cerrado after removal of the trees. Melinis minutiflora (purple inflorescence), an African grass, has invaded the system, outcompeting native grasses and forbs (photo credit AF); (c) Native grassland in Serra dos Carajás, Pará, Brazil (photo credit AJA); (d) Derived grassland replacing former forest in Carajás National Forest, Pará, Brazil (photo credit AJA); (e) Open Acacia savanna, with a continuous herbaceous layer and scattered trees and shrubs, during the wet season in Kruger National Park, South Africa; the photo also shows ostriches (Struthio camelus), which are native to these systems (photo credit DT); (f) Open Acacia savanna during the dry season, Kruger National Park, South Africa (photo credit DT).

$263 \times 274 \mathrm{~mm}(96 \times 96 \mathrm{DPI})$

This article is protected by copyright. All rights reserved. 

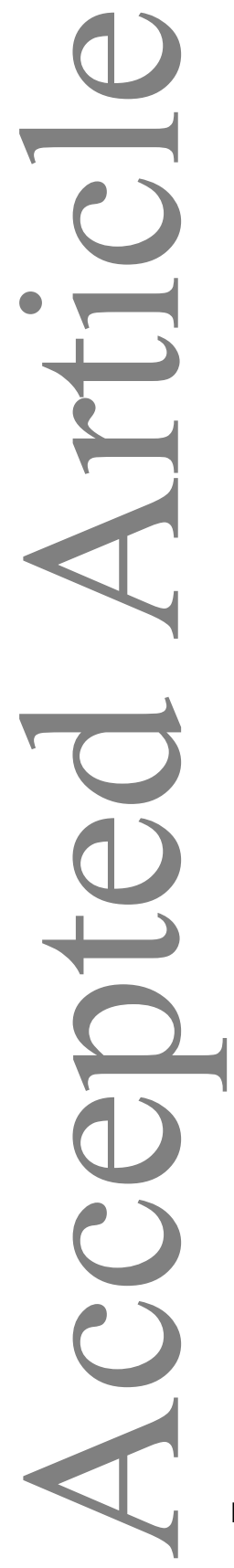
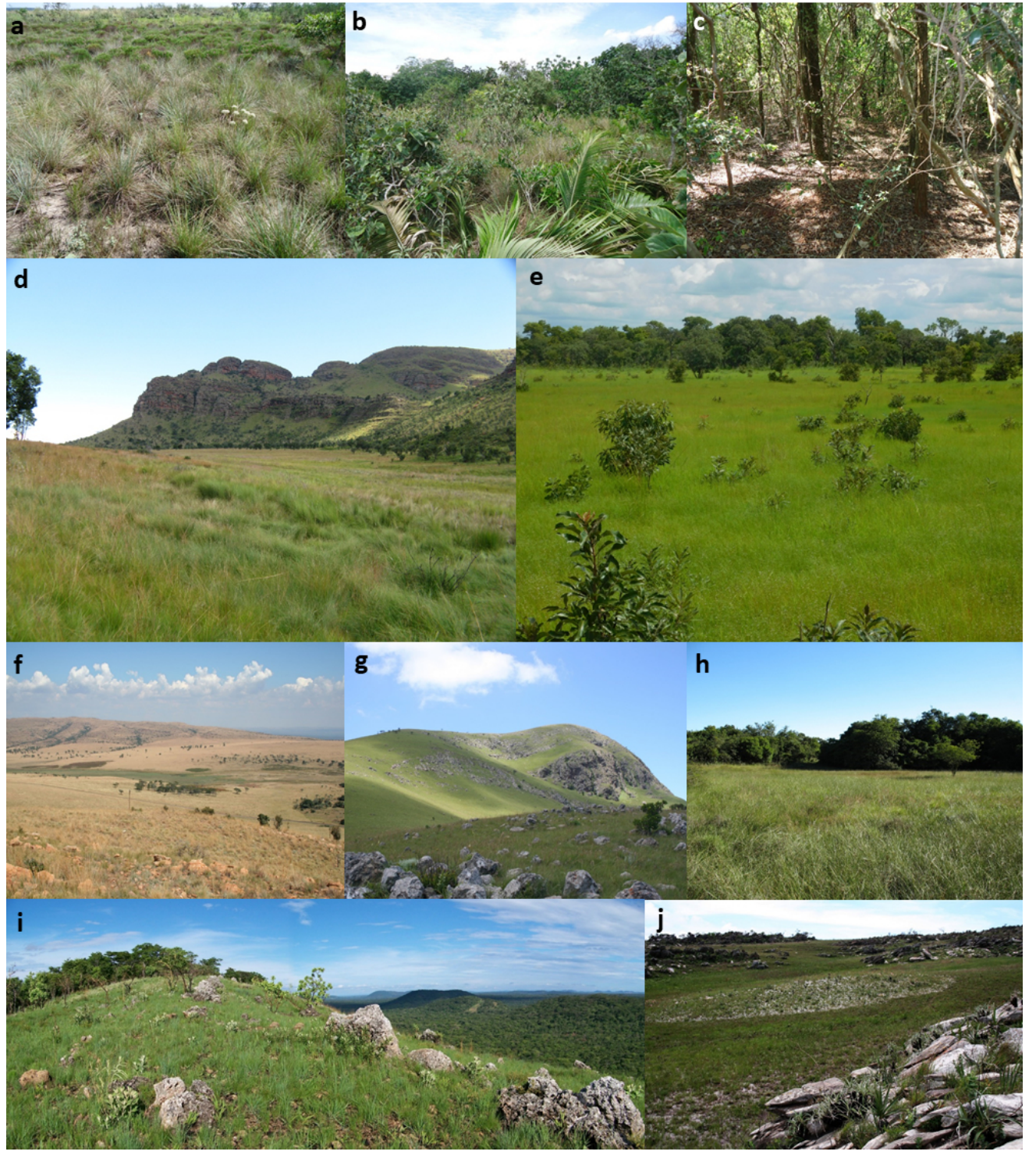

Figure 3. In many regions, grass-dominated ecosystems have existed historically as alternative states in mosaics alongside woody vegetation types, often forming a continuum from grassland and savanna to closed-canopy woodland and forest in relation to different disturbance regimes and/or environmental gradients; (a) Grassland, (b) Savanna, (c) Cerradão, a woodland, all from the Itirapina Ecological Station, Brazil (photo credit GD); (d) Grassland-Protea savanna continuum in Marakele National Park, Waterberg, South Africa (photo credit DT). Grassland or savanna and forest can also represent alternative stable states in the landscape; (e) Grassland and dense savanna in Mole National Park, Ghana (photo credit GD); ( $f$ ) Mosaic of grassland and savanna in Magaliesberg, South Africa. Mosaics of grassy and woody vegetation can also represent patterns due to edaphic factors (photo credit SJS); $g$ ) Grasslands and rocky outcrops in Swaziland (photo credit SJS); (h) Grassland-forest alternative stable states, here maintained by edaphic factors in the Soutpansberg, South Africa (photo credit DT); (i) Mosaic of grassland, savanna and forest in the Katanga copperbelt, Democratic Republic of Congo (photo credit copperflora.org); (j) Stony and sandy grasslands, as well as rocky outcrops, in Serra do Cipo, Brazil (photo credit EB).

$263 \times 297 \mathrm{~mm}(96 \times 96 \mathrm{DPI})$ 


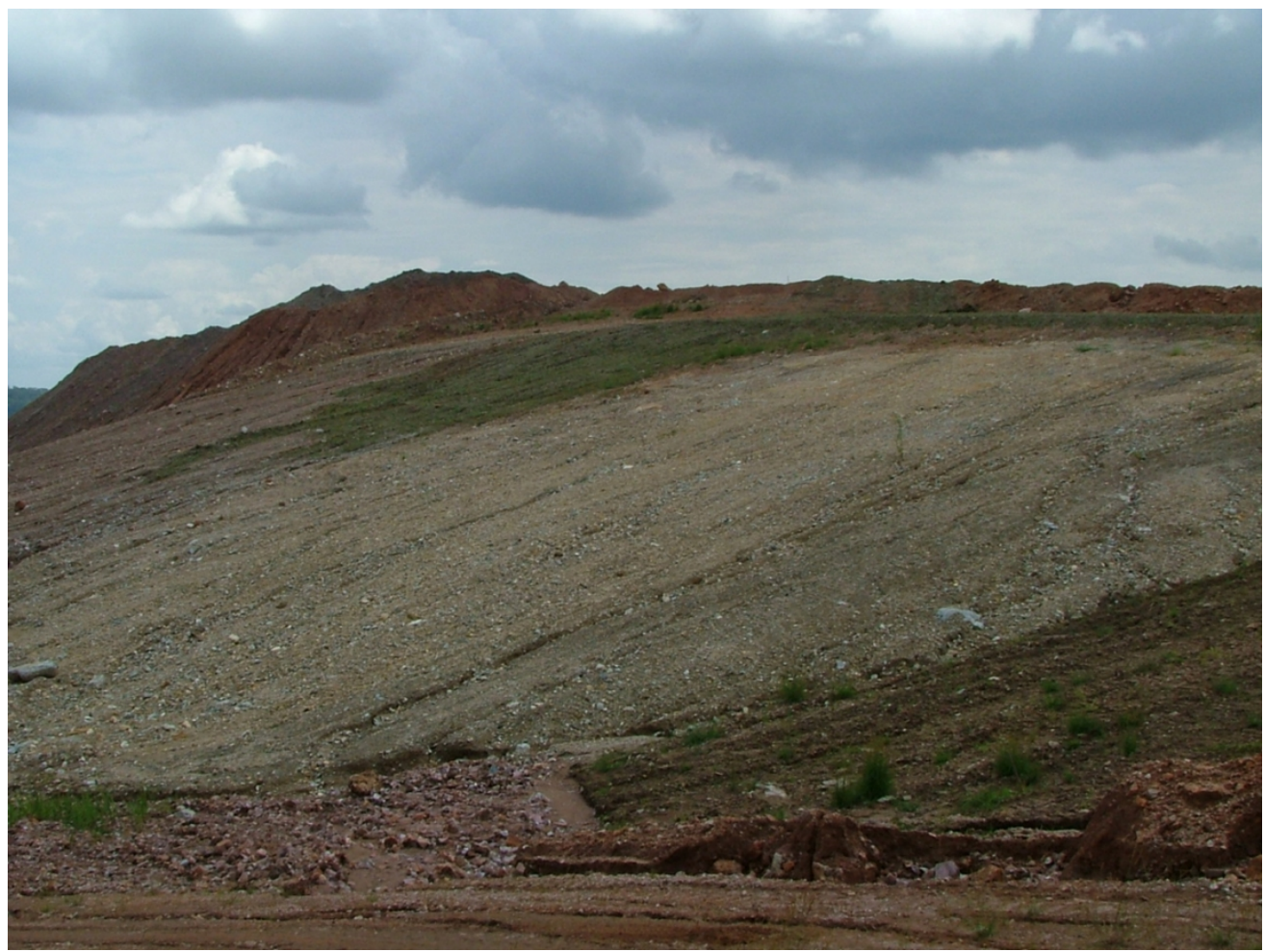

Figure 4. Large-scale earthwork often constitutes the first step in post-mining restoration. In the Katanga copperbelt, Democratic Republic of Congo, various grassland communities occur on outcrops depending on a gradient of copper $(\mathrm{Cu})$ and cobalt $(\mathrm{Co})$ concentrations. The image shows a post-mining restoration site where a hill was re-shaped to create the template for restored grassland communities. The hill comprises relatively high $\mathrm{Cu}-\mathrm{Co}$ concentration subsoil. A small area of high $\mathrm{Cu}-\mathrm{Co}$ concentration topsoil was spread on which vegetation has already established (photo credit S Le Stradic, Technische Universität München, Germany).

$355 \times 266 \mathrm{~mm}(96 \times 96 \mathrm{DPI})$

This article is protected by copyright. All rights reserved. 


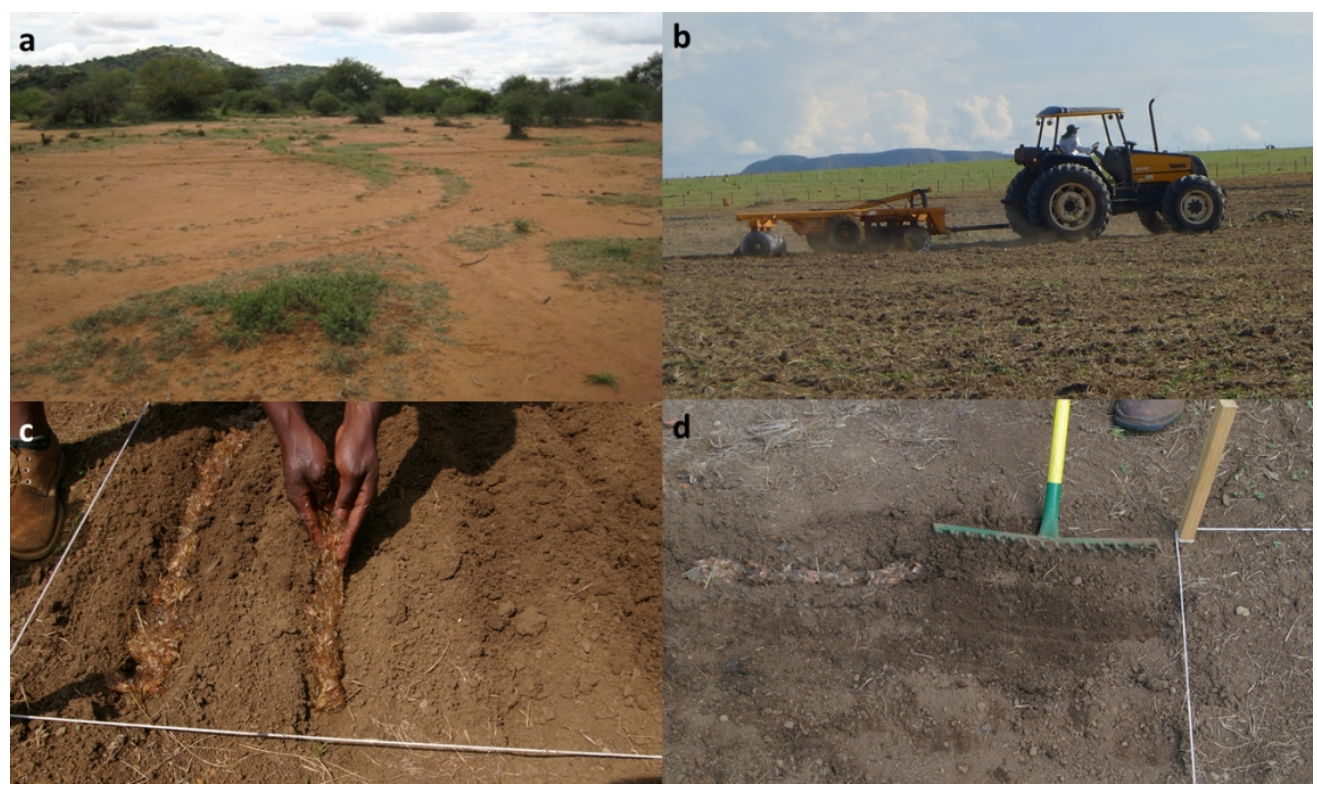

Figure 5. Soil preparation may be the first step in restoration: (a) Ripping allows the breaking up of sealed soil surfaces, leading to natural recruitment by Cynodon sp., Kenya (photo credit TPY); (b) Soil plowing before direct seeding in Chapada dos Veadeiros National Park, Brazil; many TGB species have underground storage organs that confer resilience to endogenous disturbance (Figure 6), so disrupting the soil is advised only if the degradation has already largely destroyed the underground component of the vegetation; benefits and potential negative consequences of soil preparation have seldom been studied (photo credit IS); (c) and (d) Soil preparation for seeding with Themeda triandra in gel, which provides sustained moisture for germination, South Africa (photo credits KK).

$353 \times 209 \mathrm{~mm}(96 \times 96 \mathrm{DPI})$

This article is protected by copyright. All rights reserved. 


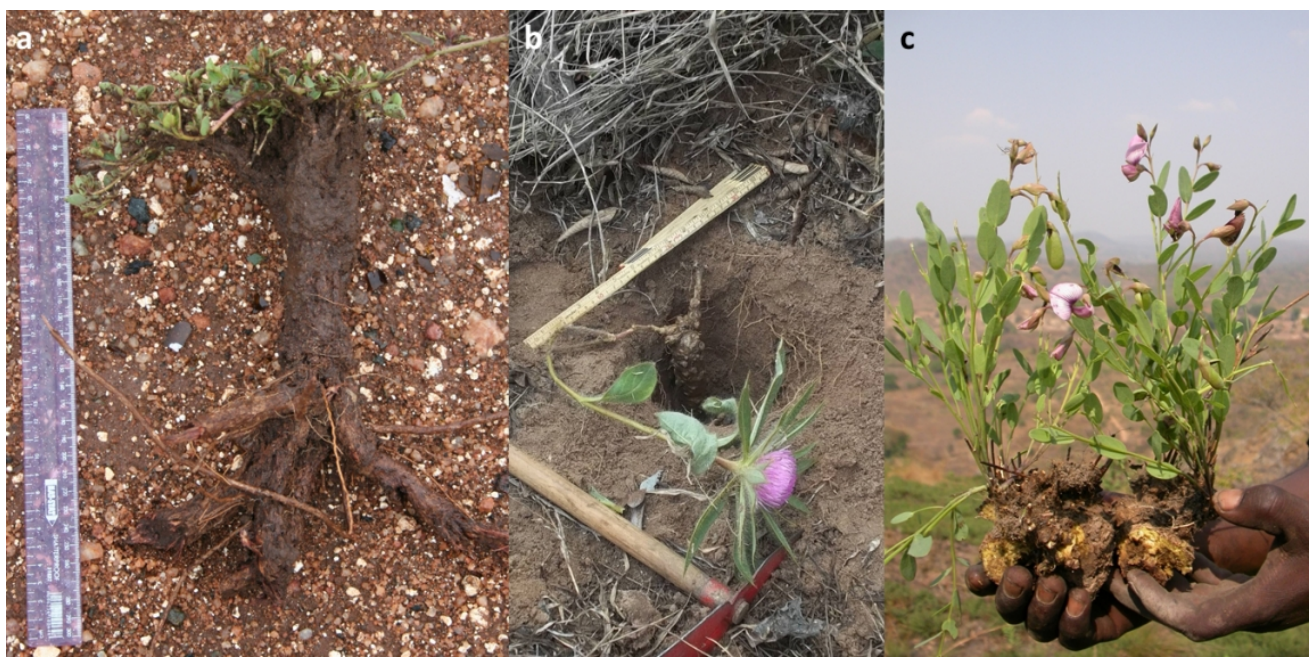

Figure 6. Non-graminoid TGB species often have underground storage organs or a bud bank that confers resilience: (a) Commicarpus pentandrus, South Africa (photo credit SJS); (b) Gomphrena macrocephala, Itirapina Ecological Station, Brazil (photo credit EB); (c) Crotalaria cornetii, Katanga, Democratic Republic of Congo (photo credit copperflora.org).

$354 \times 176 \mathrm{~mm}(96 \times 96 \mathrm{DPI})$

This article is protected by copyright. All rights reserved. 


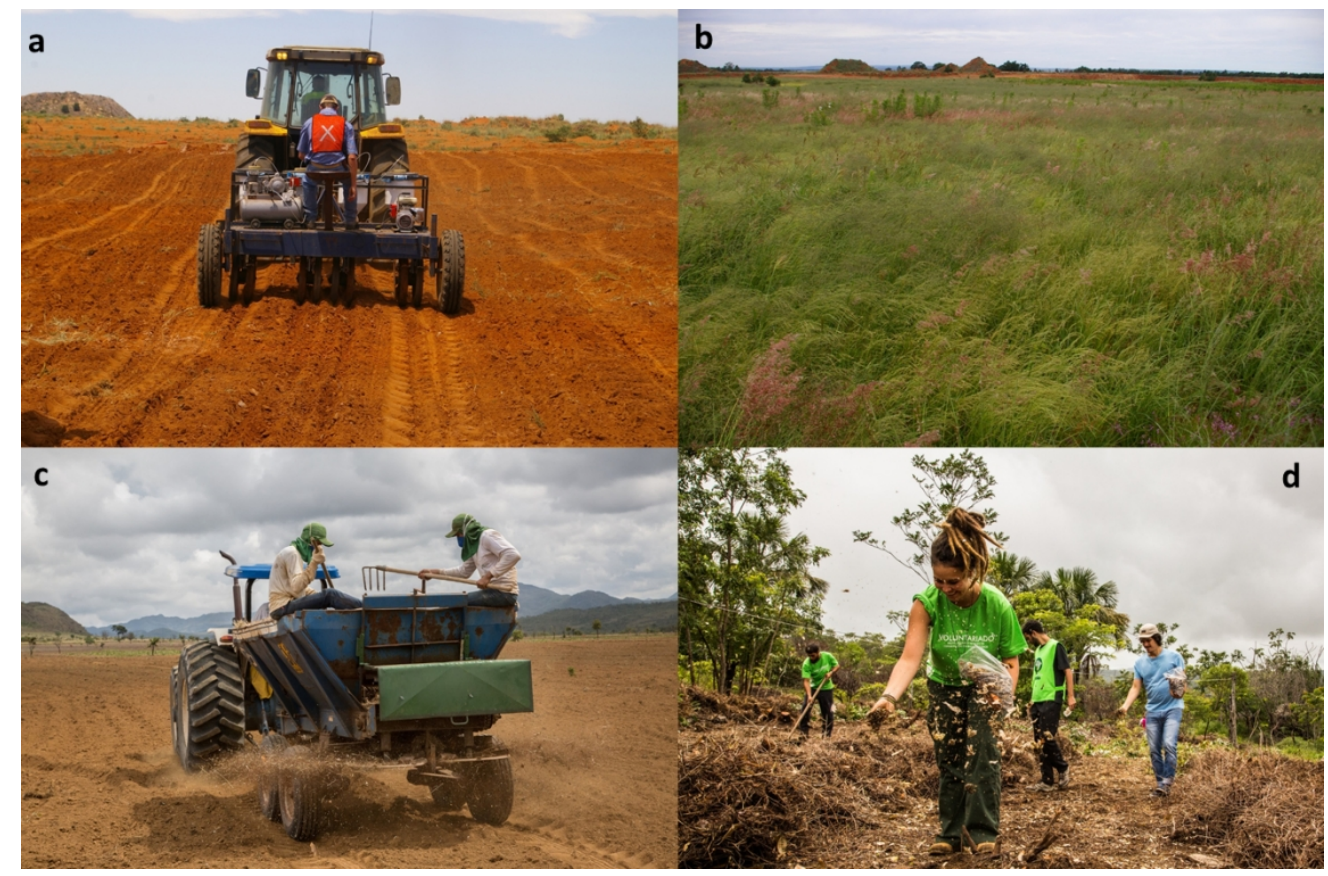

Figure 7. (a) Direct sowing of native seeds on an opencast coal mine, South Africa. Seeds were harvested from undisturbed grassland within $20 \mathrm{~km}$ of the rehabilitation site, using hand-held flail harvesters, which collected seeds from all grass and forb species present. Seeds were not separated or sorted, and were airdried and stored for one year, thereafter they were mixed into a gel and placed in the soil, in the same species ratios as harvested and (b) the same site in South Africa four years later; the dominant grass species established were Eragrostis curvula, Eragrostis racemosa, Melinis repens, Paspalum scrobiculatum, Perotis patens, Pogonarthria squarrosa, and Themeda triandra (photo credit KK); (c) Mechanized direct seeding of grasses, forbs, shrubs and trees in degraded Neotropical savanna in Central Brazil and (d) Broadcast seeding of these same life-forms performed by volunteers in Chapada dos Veadeiros National Park in Central Brazil (photo credits F Tatagiba, ICMBio).

$346 \times 228 \mathrm{~mm}(96 \times 96 \mathrm{DPI})$

This article is protected by copyright. All rights reserved. 


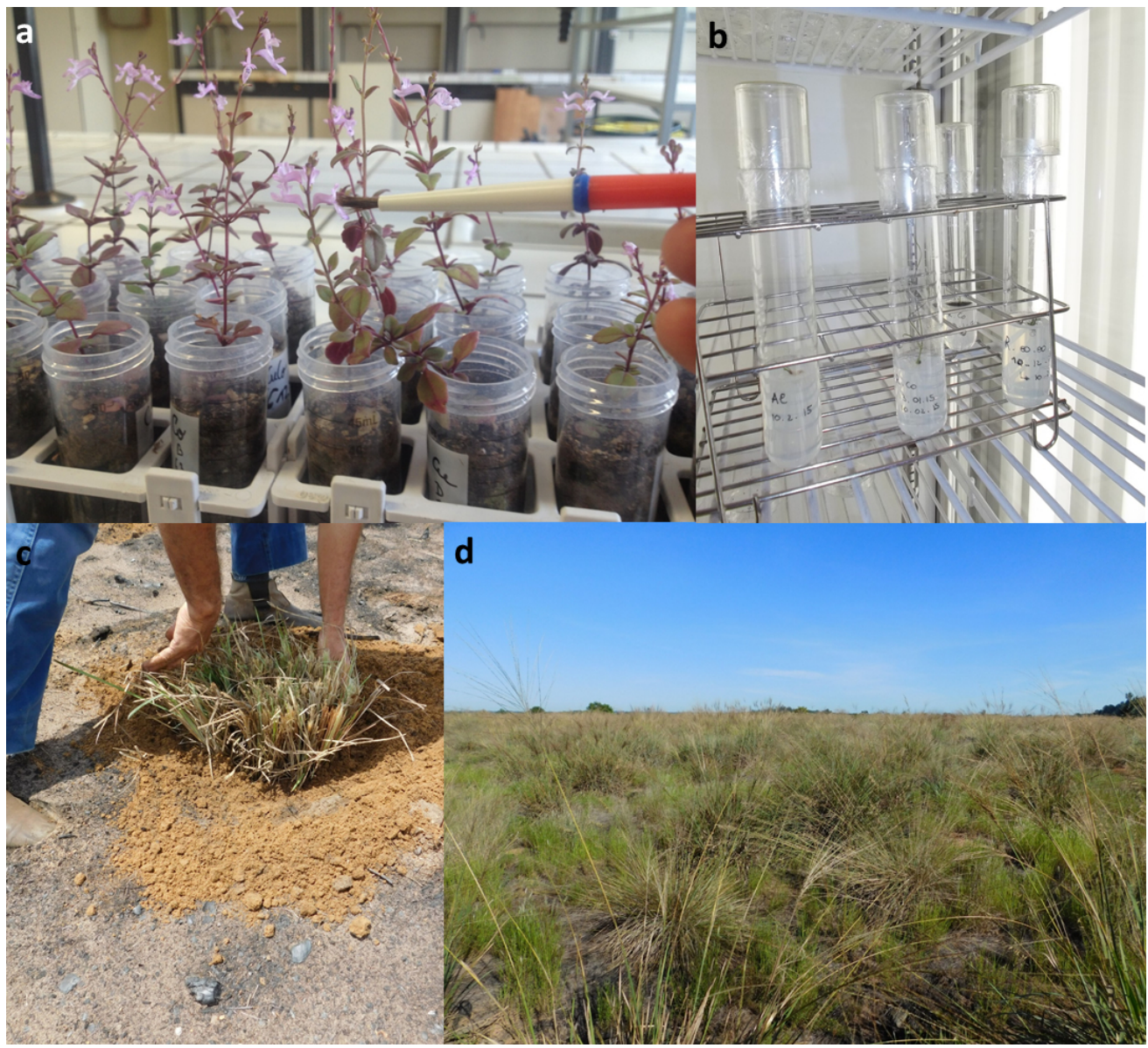

Figure 8. Reintroduction of recalcitrant species may depend mainly on vegetative propagation. Research should focus on propagating TGB plants from stem cuttings, bulbs or roots via micropropagation: (a) Identification of the niche of four populations of Aeollanthus saxatilis and propagation trials from tubers, in Katanga, Democratic Republic of Congo (photo credit copperflora.org); (b) In vitro cultivation trial of Rhynchospora consanguinea from campo rupestre grasslands, Cerrado, Brazil (photo credit EB); (c) Largescale restoration of Cerrado grassland by transplanting, in Santa Bárbara State Forest, Brazil (photo credit $\mathrm{GD}$ ); and (d) the same site three years after transplanting (photo credit GD).

$286 \times 260 \mathrm{~mm}(96 \times 96 \mathrm{DPI})$

This article is protected by copyright. All rights reserved. 


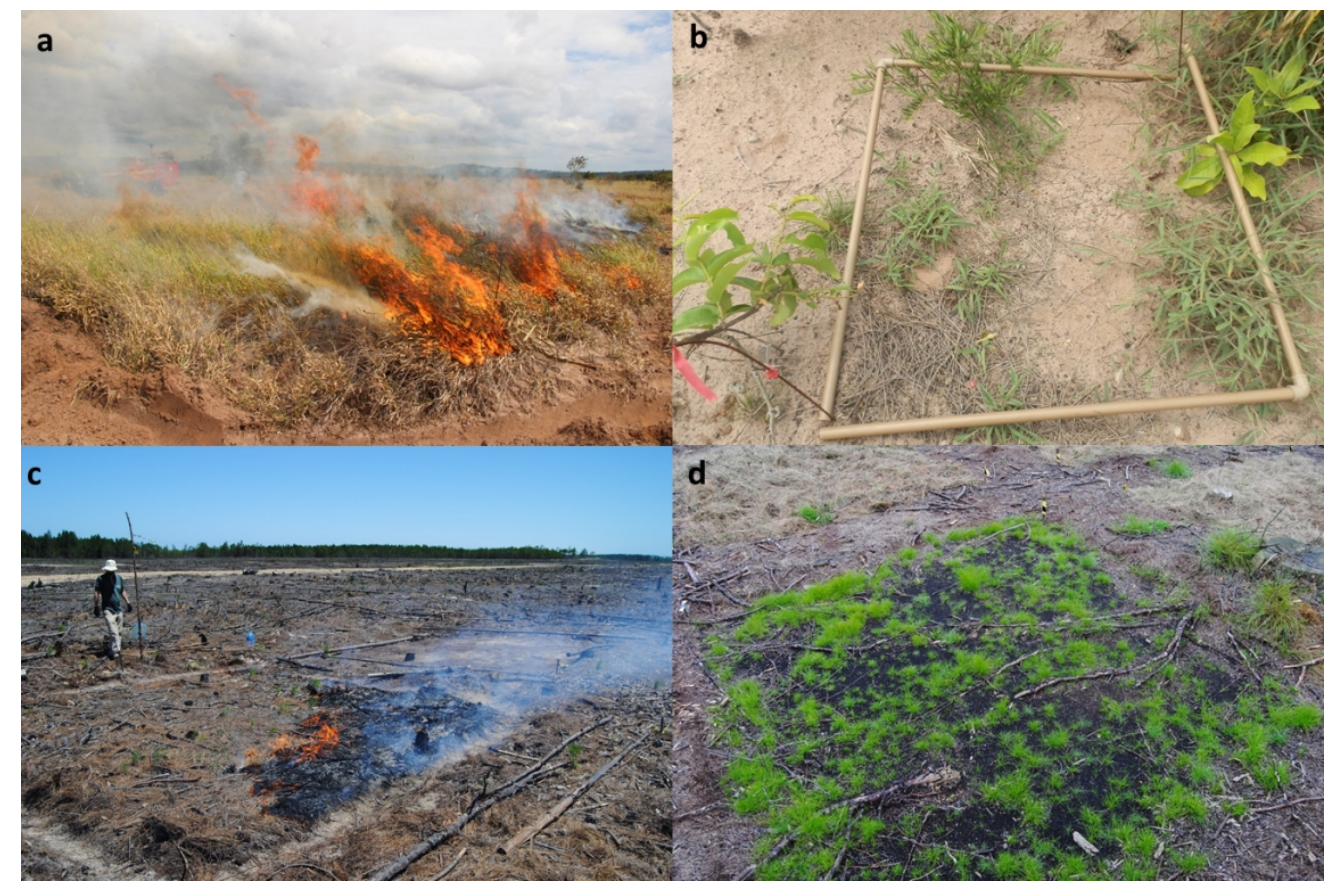

Figure 9. Prescribed fires can be used to positive effect in the restoration process: (a) Study of the effect of fire to control the invasive African grass Urochloa brizantha (syn. Brachiaria brizantha) invading the Cerrado at the Itirapina Ecological Station, Brazil (photo credit AF); (b) Study of the effect of fire to control the grass

Melinis minutiflora invading the Cerrado; the image shows the plant community after a prescribed dry season burn conducted in July 2014. The photo was taken in October 2015, at the beginning of the rainy season; M. minutiflora has germinated or resprouted, along with some native species (e.g. Eugenia punicifolia at the top of the plot, with some Cyperaceae below, Qualea grandiflora and Pradosia brevipes to the left and right of the plot, respectively, Itirapina Ecological Station, Brazil (photo credit G Damasceno, UNESP Rio Claro); (c) Study of the role of fire in removing pine litter and stimulating native species recovery after degradation of coastal grasslands by tree plantations, Lagoa do Peixe National Park, Rio Grande do Sul, Brazil and (d) Study of the role of fire in removing pine litter and stimulating native species recovery after degradation by tree plantations in highland grasslands in southern Brazil. One year after the experimental burn vegetation is dominated by native ruderal sedges from the soil seed bank, while grasses typical of the reference systems did not recruit, indicating the need for active seed introduction (photo credits GEO).

$354 \times 236 \mathrm{~mm}(96 \times 96 \mathrm{DPI})$ 


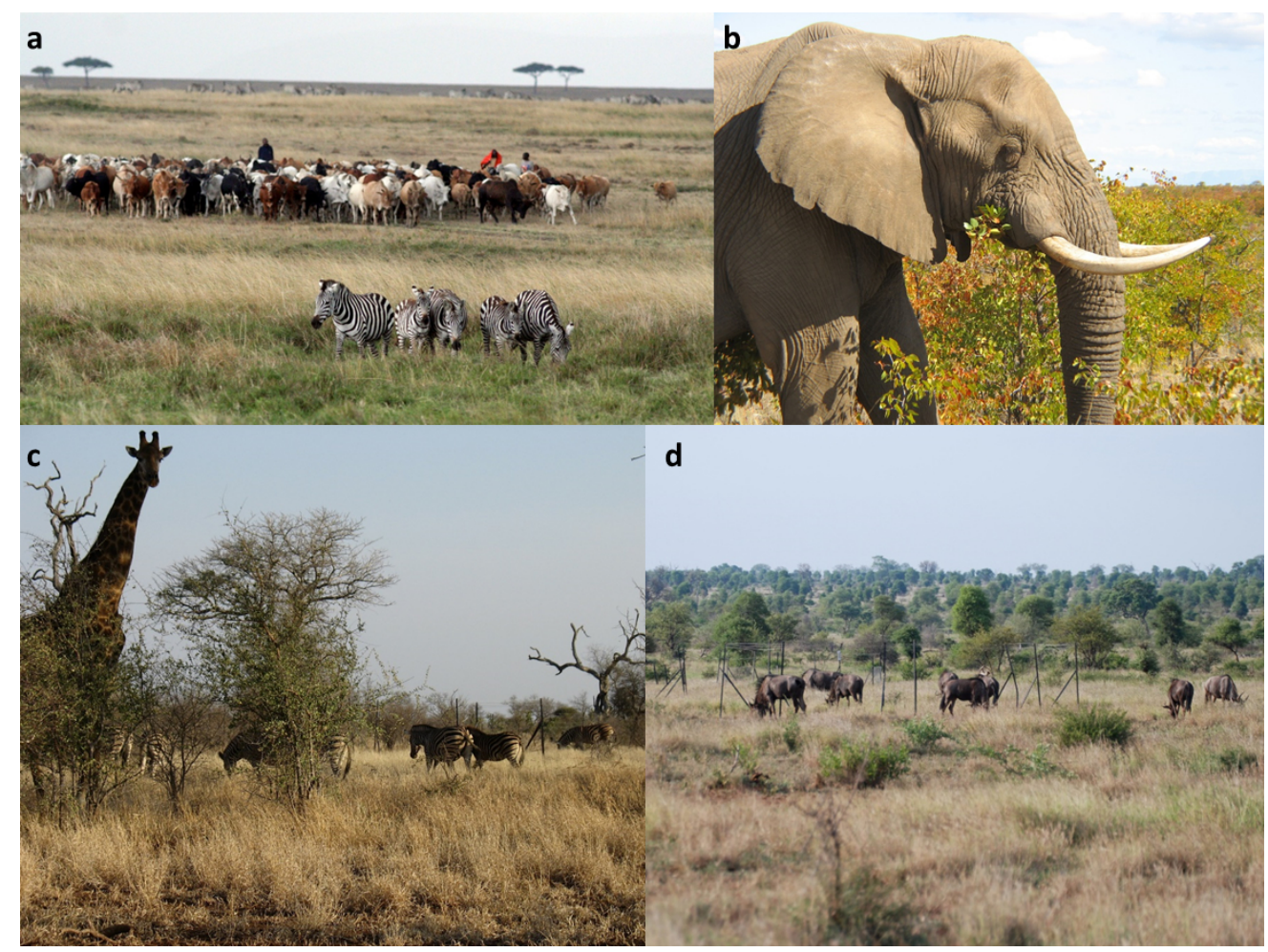

Figure 10. Maintaining an appropriate level of herbivory may entail either of two different groups of large mammalian herbivores, being native herbivores and domestic livestock: (a) Native herbivores and domestic livestock co-existing, Kenya (photo credit RM Pringle, Princeton, NJ); (b) Foraging behaviour and carrying capacities, e.g. for the African elephant Loxodonta africana, must be studied to carefully plan the restoration of diverse herbivore assemblages in savannas such as the Kruger National Park, South Africa (photo credit DT); (c) Understanding the synergistic effects of fire and herbivory on structuring the herbaceous vegetation component is critical in savanna restoration and management. Here, mixed herbivores (giraffe Giraffa camelopardalis and Burchell's zebra Equus quagga burchellii) are excluded from areas of fire-manipulated savanna, Kruger National Park, South Africa (photo credit DT) and (d) blue wildebeest Connochaetes taurinus grazing in and around an exclosure designed to preclude only the largest of the African herbivores (photo credit D Burkepile, University of California Santa Barbara).

$302 \times 227 \mathrm{~mm}(96 \times 96 \mathrm{DPI})$

This article is protected by copyright. All rights reserved. 


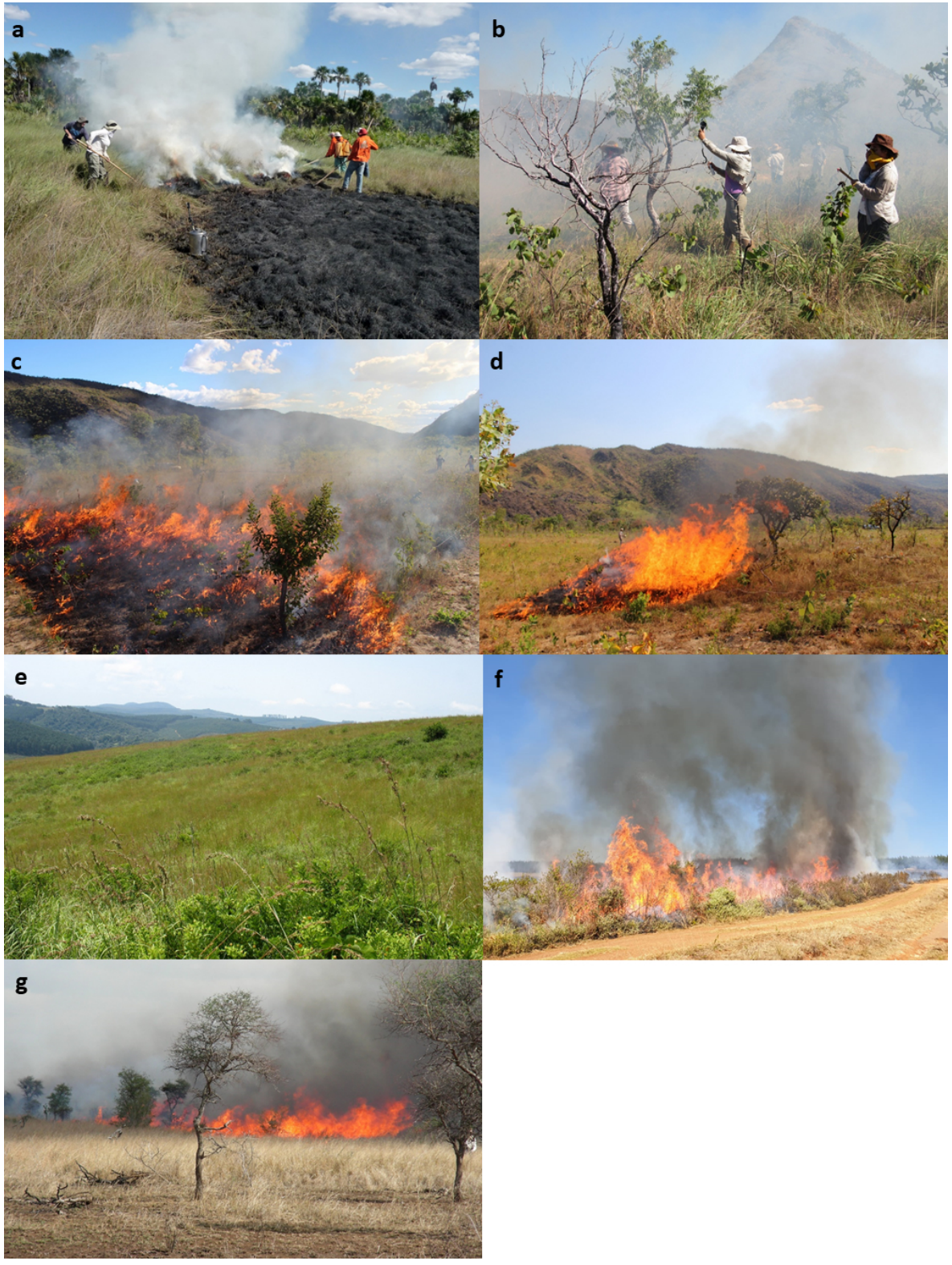

Figure 11. Maintaining fire in TGB is important, but the frequency, timing, and pattern of the fire regime must be studied: (a) Fire experiments in wet grasslands in Jalapão, Goáis, Brazil (photo credit AF); (b) Fire team measuring environmental conditions during fire experiments in Reserva Natural Serra do Tombador,

Tocantins, Brazil (photo credit AF); (c) Early dry season (July) prescribed fire and (d) late dry season (October) prescribed fire, both in Reserva Natural Serra do Tombador, Tocantins, Brazil (photo credit AF);

(e) Endangered woodbush granite grassland degraded through encroachment by woody species, Haenertsburg Nature Reserve, South Africa and ( $f$ ) prescribed fire being used to remove encroaching woody species and restore biodiversity in the same grassland (photo credit DT); (g) Fire frequency experiments have been carried out for over 60 years on experimental plots in the Kruger National Park, South Africa (photo credit D Burkepile, University of California Santa Barbara).

$$
265 \times 353 \mathrm{~mm}(96 \times 96 \mathrm{DPI})
$$

This article is protected by copyright. All rights reserved. 


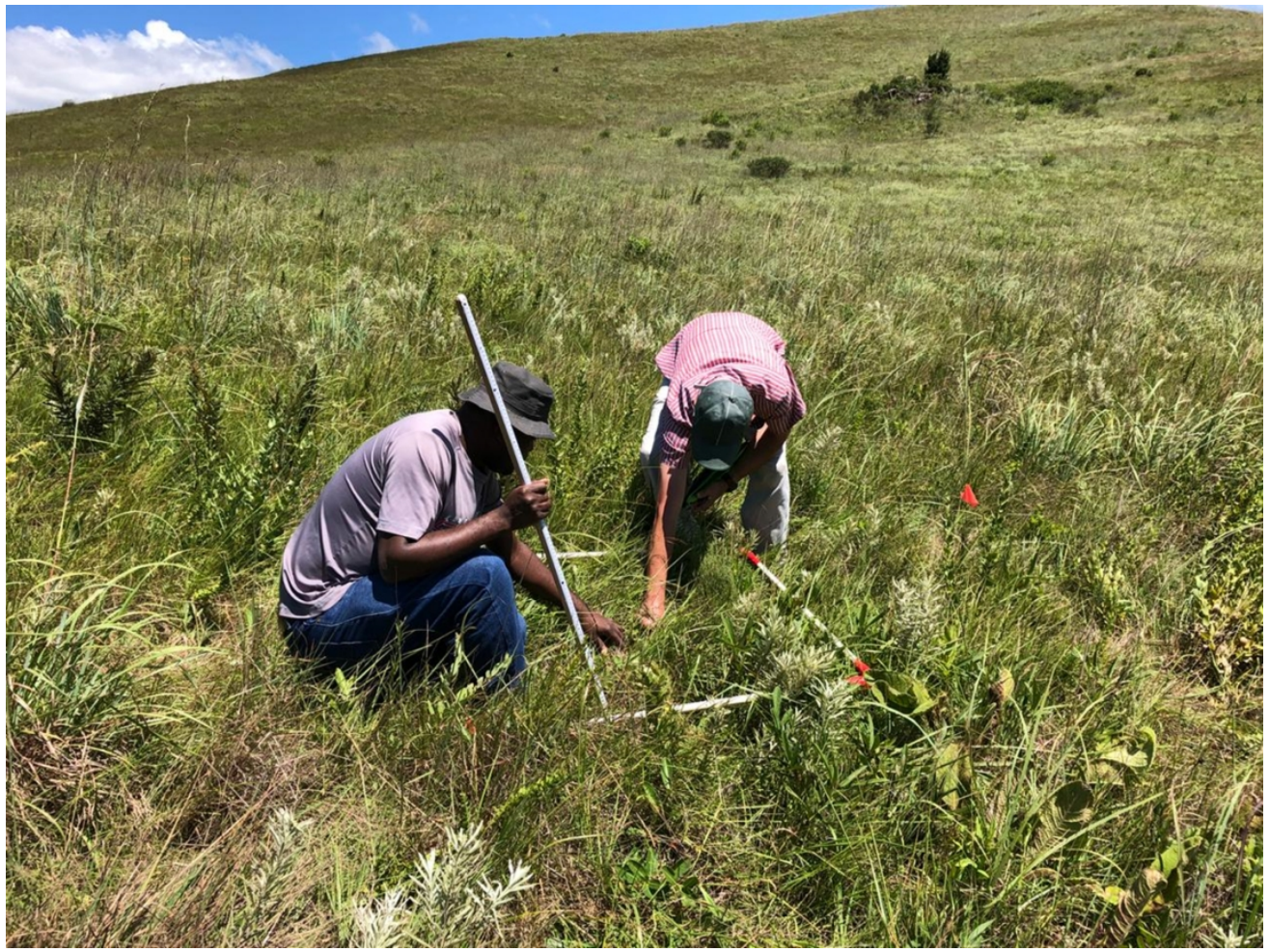

Figure 12. Sampling species diversity and functional traits in pristine TGB reference ecosystems is critical in establishing the benchmark for local restoration goals, Haenertsburg Nature Reserve, South Africa (photo credit DT).

$355 \times 266 \mathrm{~mm}(96 \times 96 \mathrm{DPI})$

This article is protected by copyright. All rights reserved. 